An Analysis of Freshwater Mussels (Unionidae) in the Upper Ohio River near Huntington, West Virginia, 1998 Studies

Andrew C. Miller and Barry S. Payne

October 2000

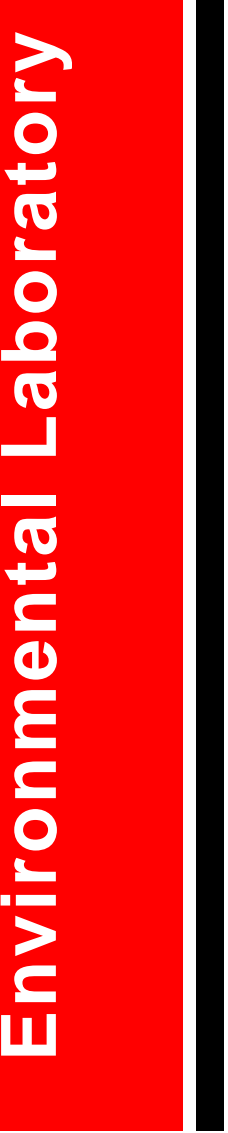


The contents of this report are not to be used for advertising, publication, or promotional purposes. Citation of trade names does not constitute an official endorsement or approval of the use of such commercial products.

The findings of this report are not to be construed as an official Department of the Army position, unless so designated by other authorized documents. 


\section{An Analysis of Freshwater Mussels (Unionidae) in the Upper Ohio River near Huntington, West Virginia, 1998 Studies}

by $\quad$ Andrew C. Miller, Barry S. Payne

Environmental Laboratory

U.S. Army Engineer Research and Development Center 3909 Halls Ferry Road

Vicksburg, MS 39180-6199

Final report

Approved for public release; distribution is unlimited 


\section{Engineer Research and Development Center Cataloging-in-Publication Data}

Miller, Andrew C.

An analysis of freshwater mussels (Unionidae) in the upper Ohio River near Huntington,

West Virginia, 1998 studies / by Andrew C. Miller, Barry S. Payne ; prepared for U.S. Army

Engineer District, Huntington.

45 p. : ill. ; 28 cm. -- (ERDC/EL ; TR-00-15)

Includes bibliographic references.

1. Unionidae -- Ohio River. 2. Freshwater mussels -- Ohio River. 3. Freshwater mussels -Field studies. I. Payne, Barry S. II. United States. Army. Corps of Engineers. Huntington District. III. Engineer Research and Development Center (U.S.) IV. Environmental Laboratory (U.S.)

V. Title. VI. Series: ERDC/EL TR ; 00-15.

TA7 E8 no.ERDC/EL TR-00-15 


\section{Contents}

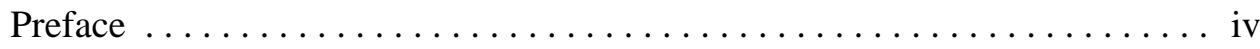

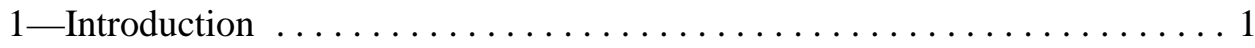

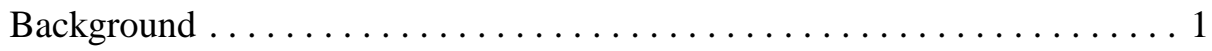

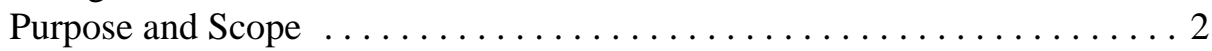

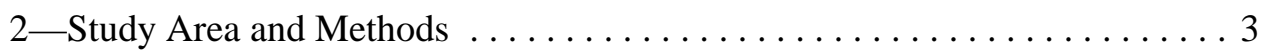

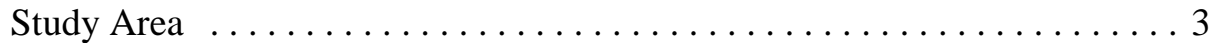

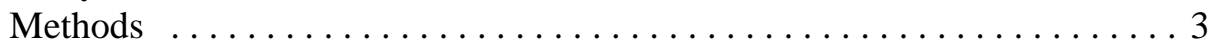

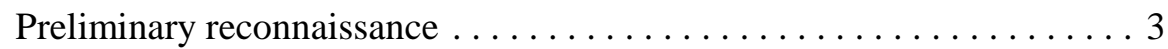

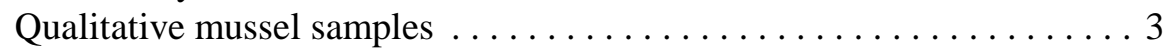

Quantitative mussel samples .................... 4

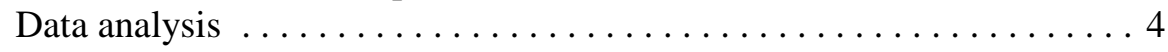

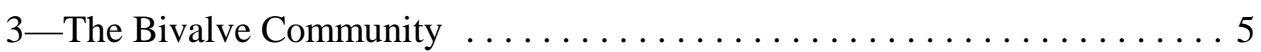

Bivalve Community Characteristics . . . . . . . . . . . . . . . 5

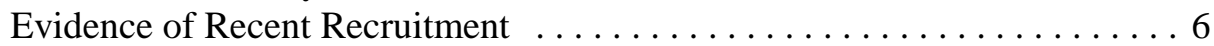

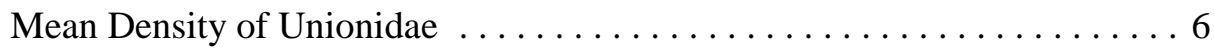

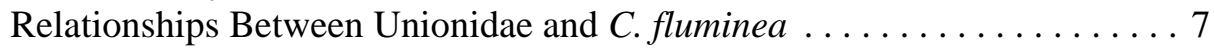

Relationship Between Unionidae and Dreissena polymorpha . . . . . . 7

Changes in Species Richness and Species Diversity . . . . . . . . 8

Size Demography of Dominant Populations $\ldots \ldots \ldots \ldots \ldots \ldots$

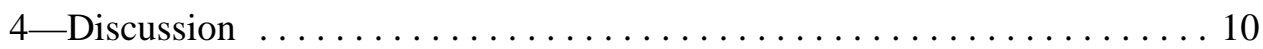

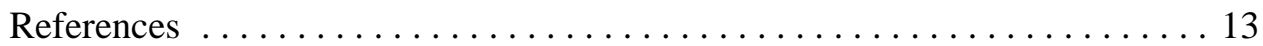

Tables 1-4

Figures 1-18

Appendix A: Freshwater Mussels Collected from Upper Ohio River

Using Quantitative Methods . . . . . . . . . . . . . . . . . . . . . A1

SF 298 


\section{Preface}

The work reported herein was conducted by the Environmental Laboratory (EL), Vicksburg, MS, U.S. Army Engineer Research and Development Center (ERDC), in July 1993 for the U.S. Army Engineer District, Huntington, Huntington, WV. The purpose was to use qualitative and quantitative methods to collect freshwater mussels (Unionidae) from known mussel beds in a reach of the Ohio River near Huntington. Data on density, size demography of dominant populations, species diversity, and community composition will be used to analyze the environmental effects of water resource developments along the upper Ohio River.

Divers were Messrs. Larry Neill and Robert T. James, Muscle Shoals, AL, and Dennis Baxter and Johnny Buchanan, Norris, TN, from the Tennessee Valley Authority (TVA). Assistance in the field and advice on location of sampling sites was provided by Mr. Bill Tolin, U.S. Fish and Wildlife Service, and Mr. Barry Passmore, Huntington District. Mr. John Campbell and Ms. Mindy Hamilton, Marshall University, Huntington, WV, assisted in the field.

During the conduct of this study Dr. John Harrison was Chief, EL; Dr. C. J. Kirby was Chief, Ecological Research Division, EL; and Dr. E. A. Theriot was Chief of the Aquatic Ecology Branch, Ecological Research Division. Safety equipment and foul weather gear were provided by TVA. Authors of this report were Drs. Andrew C. Miller and Barry S. Payne, Aquatic Ecology Branch. Design of the study and conduct of all related activities in the field and laboratory were the sole responsibility of Drs. Miller and Payne.

At the time of publication of this report, Dr. James R. Houston was Director of ERDC, and COL James S. Weller, EN, was Commander.

Miller, A. C., and Payne, B. S. (2000). "An analysis of freshwater mussels (Unionidae) in the upper Ohio River near Huntington, West Virginia; 1998 studies," ERDC/EL TR-00-15, U.S. Army Engineer Research and Development Center, Vicksburg, MS.

The contents of this report are not to be used for advertising, publication, or promotional purposes. Citation of trade names does not constitute an official endorsement or approval of the use of such commercial products. 


\section{Introduction}

\section{Background}

Freshwater mussels are long-lived (30 or more years in some species), rely on particulate organic matter for nutrition, and because they are relatively nonmotile, are unable to change their surroundings if conditions become unsuitable. Their habitat is affected by local and upriver changes in climate, season, land use, edaphic conditions, and water level. Habitat conditions are also affected by source and nonsource pollution, commodity movement, and commercial developments in the watershed. It is clear that man-made and natural disturbances in large rivers are long term, complex, and often subtle and episodic. The characteristics of freshwater mussels can make them susceptible to these disturbances. Thus these organisms and their habitats are particularly appropriate for long-term ecological studies.

The biological consequences of man-made and natural disturbances to habitat (specific physical and chemical conditions) can be measured on organisms held in the laboratory. However, caution must be used when extrapolating results of laboratory experiments to the field (Payne, Miller, and Aldridge 1987).

Physiological responses that occur in a laboratory often do not take place under natural conditions. Planners and biologists should evaluate the effects of natural and man-made disturbances on naturally occurring populations rather than on organisms held in the laboratory. Field studies are the best means of understanding effects of physical disturbances on natural populations. Studies can be designed to evaluate physical effects of water resource development on recruitment, rate of growth, density, species richness, and diversity. These parameters provide the most useful measures of the overall health and ultimate survival of a mussel community. Long-term studies on freshwater mussels in large rivers should not be discounted as "mere monitoring" (Taylor 1987). Instead, they provide an opportunity to investigate the effects of complex, episodic events on a resource with ecological, economic, and cultural value. 


\section{Purpose and Scope}

The purpose of this study was to characterize important biotic variables (mussel density, evidence of recent recruitment, community structure, and spatial distribution) of mussel beds downriver of the Robert Byrd Lock and Dam in the Ohio River, West Virginia. Results will be used to evaluate effects of water resource developments on freshwater mussels. In addition, data will be used to assess effects of the exotic zebra mussel (Dreissena polymorpha) on native freshwater mussels. 


\section{Study Area and Methods}

\section{Study Area}

The Ohio River originates in Pittsburgh, PA, at the confluence of the Allegheny and Monongahela Rivers. It flows $1,578 \mathrm{~km}$ (981 miles) to the northwest and then the southwest before it joins the Mississippi River near Cairo, IL. The river drains 528,101 sq km (203,900 square miles) and falls $137 \mathrm{~m}$ (450 ft) before it joins the Mississippi River.

For this project, study sites were located in the upper Ohio River (UOR) between River Miles (RM) 292 and 284 (Table 1, Figures 1-3). Quantitative and qualitative methods were used to collect bivalves at RM 287, 292, 289, and 284 (Table 1, Figures 2, 3). The majority of samples were collected about $61 \mathrm{~m}$ (200 ft) from shore in water between 3.7 and $7.6 \mathrm{~m}$ (12 and $25 \mathrm{ft}$ ) deep. Global Positioning System (GPS) coordinates for each mussel bed are listed in Table 1.

\section{Methods}

\section{Preliminary reconnaissance}

All underwater work was accomplished by a dive crew equipped with surface- supplied air and communication equipment. Before intensive sampling was initiated, a single diver conducted a preliminary reconnaissance of the immediate area. He obtained information on substratum type, water velocity, and presence of mussels to determine if he was on the mussel bed and would be able to collect specimens using quantitative methods. Since this river reach was studied in 1992 and 1993, some knowledge was available on the approximate location of mussel beds (Miller and Payne 1993, 1995).

\section{Qualitative mussel samples}

The majority of the qualitative samples were obtained by having two divers collect simultaneously. Each diver placed a specific number of live mussels in each of six nylon bags; 5 mussels were placed in three bags and 20 were placed 
in each of the other nine bags. At each site 12 samples and approximately 200 individuals were collected. Divers were instructed to obtain mussels without bias toward size or type. They attempted to exclude the Asiatic clam, Corbicula fluminea. If $C$. fluminea was inadvertently collected, it was later eliminated. A total of 84 qualitative samples (bags of mussels) were taken at four mussel beds (Table 1).

All mussels were brought to the surface, counted, and identified. Data were recorded on standard data sheets and returned to the laboratory for analysis and plotting. Shells of voucher specimens for each species were placed in plastic zip-lock bags and labeled with high-rag-content paper. Mussels not needed for voucher were returned to the river. Methods for sampling mussels are based on techniques described in Miller and Nelson (1983); Isom and Gooch (1986); Kovalak, Dennis, and Bates (1986); Miller and Payne (1988); and Miller et al. (1993). Mussel identification was based on taxonomic keys and descriptive information in Burch (1975), Cummings and Mayer (1992), and Parmalee and Bogan (1998). Taxonomy is consistent with Williams et al. (1993).

\section{Quantitative mussel samples}

Quantitative samples (that included unionids as well as C. fluminea) were obtained at RM 287, 292, 290, and 284. At each mussel bed, bivalves were collected at each of two to five sites that were separated by 5-10 m. At each site, 10 quadrats $(0.25 \mathrm{sq} \mathrm{m})$ were positioned approximately $1 \mathrm{~m}$ apart. A diver excavated all sand, gravel, shells, and live bivalves to a depth of 100-150 mm. Material was sent to the surface in a 20-L bucket and transported to shore. Sediment was screened through a sieve series. All live mussels and C. fluminea removed from samples were placed in 4-L zip-lock bags. Each bivalve was then identified and total shell length (SL) measured to the nearest $0.1 \mathrm{~mm}$ with digital calipers. Bivalves were processed in the field and returned to the river unharmed.

\section{Data analysis}

Species diversity $H^{\prime}$ was determined with the following formula:

$$
H^{\prime}=-\left(p_{j} \log p_{j}\right)
$$

where $p_{j}$ is the proportion of the population that is of the $j^{\text {th }}$ species (Shannon and Weaver 1949). Evenness was calculated with the modified Hill's ratio (Ludwig and Reynolds 1988). All calculations were done with programs written in BASIC or SAS (Statistical Analytical System) on a personal computer. Discussion of statistical procedures that were used can be found in Green (1979) and Hurlbert (1984). Species area curves and dominance-diversity curves were constructed from qualitative and quantitative biological data. More information on methods used for this survey can be found in McNaughton and Wolf (1973), Isom and Gooch (1986), Kovalak, Dennis, and Bates (1986), Miller and Payne (1988), and Miller et al. (1993). 


\section{The Bivalve Community}

\section{Bivalve Community Characteristics}

Over 1,200 freshwater mussels representing 22 species were collected in the study area using qualitative methods (Table 2). Three more species were collected using qualitative than quantitative methods (a total of 19). Qualitative sampling typically generates a longer species list simply because more organisms are collected. However, the quantitative collecting has the advantage of obtaining the smaller species and individuals that divers can miss searching by hand when visibility is low.

A total of 30 species of freshwater mussels, not counting the nonindigenous zebra mussel (D. polymorpha) or Asian clam (C. fluminea), have been collected in this river reach since the beginning of this project (Table 2). Differences in the total species count each year are caused by slight variations in the sampling locations or simply chance. For species that represent less than 0.01 percent of the community, it is obvious that several thousand mussels might have to be obtained before one individual of that species is collected.

Based upon qualitative collecting at three sites, the fauna was dominated by two thick-shelled species (Elliptio crassidens and Quadrula pustulosa pustulosa), which composed 44.18 and 13.76 percent of the assemblage, respectively. Elliptio crassidens was taken in more than 90 percent of the samples and $Q$. p. pustulosa, which was much less abundant, was taken in slightly more than 80 percent of the samples. Eleven species represented from 1 to 10 percent of the fauna, and ten species made up less than 1 percent of the fauna. With the exception of two species, the majority of the mussels were either fairly common or rare. Virtually all of the mussels have massively thick shells such as those belonging to the genera Quadrula, Elliptio, Fusconaia, Amblema, or Megalonaias. Species that did not belong to this group included Leptodea fragilis, which has a very thin shell, and Potamilus alatus, which has a slightly thicker shell. Thin-shelled species were uncommon in the study area.

A total of 188 individuals and 19 species were collected in 120 quantitative samples (Tables 2 and 3 and Appendix A). Quadrula p. pustulosa, E. crassidens, and Obovaria reflexa composed 26.6, 18.1, and 15.4 percent of the Unionidae (Table 3). Fourteen species were between 1 and 7 percent of the 
fauna and two species (Lasmigonia complanata and Lampsilis teres) composed less than 1 percent of the fauna. As stated previously, fewer species (19) were taken using quantitative rather than qualitative methods (22 species, Table 2).

This was the result of the large number of individuals collected using qualitative methods $(1,279)$ compared with quantitative methods (188).

\section{Evidence of Recent Recruitment}

An indicator of recent recruitment is the percentage of individuals and species less than $30 \mathrm{~mm}$ total shell length. This will include all Unionidae less than 2-3 years old regardless of species. Based upon data obtained in 1992 and 1993, recent recruitment was low in this river reach (Figures 4 and 5). In 1992 and 1993, less than 10 percent of all native mussels collected were less than $30 \mathrm{~mm}$ total shell length. In 1998 the percentage of individuals less than $30 \mathrm{~mm}$ ranged from 14 to 41 percent at three locations, a notable increase. In 1992 less than 20 percent of the species showed evidence of recent recruitment. In 1993 recent recruitment was evident only at RM 287; none was found at the other locations. In 1998 more than 20 percent of the mussel species collected at each of three locations (RM 284, 287, and 290) showed evidence of recent recruitment.

The only species showing evidence of recent recruitment in 1992 were Truncilla truncata and $Q$. p. pustulosa. The only species besides $Q . p$. pustulosa showing evidence of recent recruitment in 1993 were $T$. truncata and $O$. reflexa. In 1998 a total of nine species showed evidence of recent recruitment:

A. p. plicata, E. lineolata, L. fragilis, O. reflexa, P. alatus, Q. p. pustulosa, Q. quadrula, T. truncata, and T. donaciformis.

\section{Mean Density of Unionidae}

Mean densities were low in 1998 in this reach of the river; maximum density was less than 8 individuals/sq $\mathrm{m}$ at RM 284 and 287 (Figure 6). Mean unionid densities have always been low in this river reach (Figure 7). Mean density ranged from 7.9 to 13.7 in 1992, from 3.6 to 13.4 in 1993 , and from 0.8 to 11.2 in 1998. Although densities were variable among years and sites during any one year, there appears to be no specific trend with respect to native mussels. Mean densities were either similar to or greater than previous years in the beds at RM 284, 287, and 290. The extreme reduction in density at RM 292 in 1998 is difficult to explain; however, it could be due to loss of an older cohort or simply spatial variation in mussel abundance. 


\section{Relationships Between Unionidae and C. fluminea}

Mean density of $C$. fluminea was moderately high, 80 to 100 individuals/sq m at RM 287 and 290 (Figure 8). High-density populations of $C$. fluminea were found in 1992 and 1993 (Figure 9). In 1992 mean densities at RM 284 exceeded 3,000 individuals/sq m. In 1998 mean density of all C. fluminea populations at all locations was less than 500 individuals/sq m. At two locations (RM 284 and 290) mean densities were less than 100 individuals/sq m. Density of this species has declined dramatically in this reach of the UOR since these surveys began.

Various authors have reported that high densities of $C$. fluminea could negatively affect native freshwater mussels by competing for food and space. After many years of detailed study in the lower Ohio River, Miller and Payne (1994) were unable to demonstrate any positive or negative relationship between nonindigenous and native bivalves. It appears that densities of Corbicula are gradually decreasing, and obviously there will be only limited interactions between these species in the future.

\section{Relationship Between Unionidae and Dreissena polymorpha}

The zebra mussel, D. polymorpha, has now become part of the bivalve fauna throughout the Mississippi River from Wisconsin to New Orleans and virtually all of the Ohio River. Only eight zebra mussels were collected at these sites during 1993. All were located at RM 292.0 and were obtained in quantitative samples; estimated density was $1.6 / \mathrm{sq} \mathrm{m}$. Dreissena polymorpha, unlike $C$. fluminea, can byssally attach to unionids in high numbers. Therefore, there is potentially much more direct competition between zebra mussels and native mussels than between zebra mussels and Asian clams.

Based upon results of quantitative sampling in 1998, mean density of zebra mussels in the substratum was estimated at less than 100 individuals/sq $\mathrm{m}$. Zebra mussels were attached to cobble and gravel, dead shells, and live mussels. The number of attached zebra mussels on each native mussel was counted to determine infestation rate. Fifteen percent of the native mussels harbored no attached zebra mussels, and 41.5 percent had from one to nine attached zebra mussels. Only 18.5 percent were considered to be heavily infested, and had more than 50 attached zebra mussels, as shown in the following tabulation. 


\begin{tabular}{||l|l||}
\hline Infestation Level & Percentage of Unionids \\
\hline Not infested & 41.5 \\
\hline Less than 10 zebra mussels & 25.0 \\
\hline Between 10 and 50 zebra mussels & 18.5 \\
\hline More than 50 zebra mussels & 15.0 \\
\hline
\end{tabular}

In the early 1990s extremely high densities of zebra mussels were found at a dense and diverse mussel bed in the lower Ohio River near Olmsted, IL (Miller and Payne 1997). In August 1994, mean densities at some locations on the mussel bed were as high as 300,000 individuals/sq m. In July 1995, this cohort ranged from 11.3 to nearly $27.3 \mathrm{~mm}$ total shell length. Mean density at most sites was 20,000 to 50,000 individuals/sq mm. Between July and October of 1995 the majority of the mussels in that cohort died. Mean density of the zebra mussels at that site was less than 100 individuals/sq $\mathrm{m}$, and shell length ranged from 1.4 to $20.2 \mathrm{~mm}$. Quantitative samples have been taken at that bed every year since 1993; although zebra mussels are still at that site, their numbers are typically less than $1,000 / \mathrm{sq} \mathrm{m}$.

\section{Changes in Species Richness and Species Diversity}

Overall richness and diversity of species collected in this reach of the Ohio River (qualitative and quantitative samples combined) have gradually increased during the study period (Figure 10). In 1992, 21 species were collected; in 1993, 25 species were found; and in 1998, a total of 26 species were collected. So far, 30 species have been found at this location. Shannon's diversity index (calculated for all the mussels collected using qualitative methods) was higher in 1998 than in either of the previous 2 years. This slight increase was probably the result of a more even distribution of species in these latter collections.

\section{Size Demography of Dominant Populations}

Unionid density was low at RM 284 and 287 and extremely low at RM 290 and 292 (Figure 6). Mean density was approximately 7.2 and 6.2 individuals/sq $m$ at sites with moderate density, and less than 1.0 individual/sq $\mathrm{m}$ at sites with low density. Despite such low densities, unionids showed substantial evidence of recent recruitment, evident in the population size structure of the most abundant species. For example, 13 of 50 Q. p. pustulosa were less than $30 \mathrm{~mm}$ long; the smallest was only $14 \mathrm{~mm}$ long (Figure 11). The estimated age of Q. p. pustulosa ranging from 15 to $30 \mathrm{~mm}$ is 2 to 4 years. The largest $Q$. $p$. pustulosa obtained was $65 \mathrm{~mm}$ long-a very large adult of this species in the UOR. 
In contrast, E. crassidens showed no evidence of recent recruitment (Figure 12). All individuals of this species were greater than $90 \mathrm{~mm}$ long. The largest individual obtained was $170 \mathrm{~mm}$ long — a very large adult of this species. The moderate sample size $(n=34)$ did not allow a conclusion that absolutely no recent recruitment of this species had occurred. However, if moderate recent recruitment had occurred, a few small mussels would have been obtained. Thus, at best, recent recruitment of this species has been low, and no recruitment has occurred recently.

Recent recruitment was clearly evident in the A. p. plicata population, although no large adults were present (Figure 13). Only 13 individuals of this species were obtained. Nearly all of these were recent recruits 12 to $30 \mathrm{~mm}$ long that were likely 1 to 3 years old. The largest individual was only $47 \mathrm{~mm}$ long; individuals of this species commonly often attain maximum lengths of more than $90 \mathrm{~mm}$.

The $O$. reflexa population was similar to that of $Q . p$. pustulosa in that there was evidence both of recent recruitment and occurrence of large adults (Figure 14). Six of fifteen individuals obtained of this species were less than $30 \mathrm{~mm}$ long and represented recent recruitment. Four individuals were 40 to $50 \mathrm{~mm}$ long. Although $50 \mathrm{~mm}$ is not an absolute maximum length in the Ohio River, this length is certainly a large adult size for this species.

Corbicula fluminea density was greatest at RM 287 and 290, averaging 108 and 85 individuals/sq m, respectively (Figure 8). Density at RM 284 and 292 averaged less than 40 individuals/sq $\mathrm{m}$. All of these density values are low for this species, which can often be more than 1,000 individual/sq $\mathrm{m}$ in suitable habitats.

Size structure of $C$. fluminea population varied among sites. At RM 284, individuals ranged from 5 to $20 \mathrm{~mm}$, and two cohorts were evident (Figure 15). One was centered at $10 \mathrm{~mm}$ and the second at approximately $15 \mathrm{~mm}$. At RM 287, individuals ranged from 7 to $27 \mathrm{~mm}$, but only one cohort was evident between 7 and $20 \mathrm{~mm}$ (Figure 16). At RM 290 (Figure 17), individuals ranged from 5 to $21 \mathrm{~mm}$, and two cohorts were present. The major cohort was centered at $10 \mathrm{~mm}$, and a minor cohort was centered at approximately $14 \mathrm{~mm}$. At RM 292 individuals ranged from 4 to $18 \mathrm{~mm}$, and two cohorts were present (Figure 18). The major intersite differences probably reflect combined effects of variable cohort strength and individual growth rates among sites. 


\section{Discussion}

The fauna in this reach of the UOR consisted almost entirely of thick-shelled species such as E. crassidens, $Q$. p. pustulosa, with lesser numbers of $Q$. metanevra and Pleurobema cordatum. Thin-shelled species such as pyganodon spp. and $L$. fragilis were either absent or very uncommon. Each year slightly more species have been collected (Figure 10, Table 4). There is simply no indication that species are being lost from this reach of the river, or that community composition is changing greatly. Conditions actually appear to be improving.

Total species richness in the study area (30 species based on quantitative and qualitative sampling since 1992 (Table 2) is similar to that at other mussel beds in large rivers. At a mussel bed in the lower Ohio River near Olmsted, 26 species of freshwater mussels were collected using qualitative and quantitative methods (Miller, Payne, and Siemsen 1986). In a survey of the lower Tennessee River, Miller, Payne, and Tippit (1992) collected 4,768 individuals and identified 23 species.

In 1993 a single specimen of Lampsilis abrupta (Say, 1831), listed as endangered by the U.S. Fish and Wildlife Service (1991), was collected during qualitative searches by divers at RM 287.2 (Table 2). This species was not collected in 1992 or 1998. Although this species has been collected at other locations in the UOR (Tolin, Schmidt, and Zeto 1987), L. abrupta is obviously very uncommon. Density of this species must be less than $0.0168 / \mathrm{sq} \mathrm{m}$ (less than 1 individual/ $60 \mathrm{sq} \mathrm{m}$ ). It should be noted that even at extremely low densities (1/100 sq $\mathrm{m}$ ) there could be many tens of L. abrupta in this river reach.

Another uncommon species of some concern is Plethobasus cyphyus, listed as endangered by the Commonwealth of Kentucky (Branson et al. 1981). This species was collected in all 3 years. It has been found in a dense and diverse bed in the lower Ohio River near Olmsted (Payne and Miller 1994), and composed 0.19 percent of the fauna at a site stabilized by wing dams in Pool 10 of the upper Mississippi River (Miller 1988).

These mussel beds in this reach of the Ohio River can be characterized as having extremely low density (Figure 7). Mean density each year was less than 14 individuals/sq $\mathrm{m}$. Spatial and temporal density differences have been notable. 
At RM 290, density in 1998 was almost double that in 1993. However, at RM 292 mean density was substantially less than in 1992 and 1993. Mean density at RM 284 and 287 was approximately the same each study year. These density data are less than values often found at other large river mussel beds. In the lower Tennessee River, Miller, Payne, and Tippit (1992) estimated total density to range from 9.2 to 128.0 individuals/sq $\mathrm{m}$ at six closely placed sites. In a survey of the upper Mississippi River, Miller et al. (1990) reported that total mussel density ranged from 5.2 to 333.2 individuals/sq $\mathrm{m}$ at 16 sites. At half of those sites, total density was greater than 50 individuals/sq $\mathrm{m}$ and at four sites it was greater than 100 individuals/sq $\mathrm{m}$. At an inshore and offshore site sampled in 1986 at RM 18.6 in the lower Tennessee River, total mussel density was 187.7 and 79.7 individuals/sq m, respectively (Way, Miller, and Payne 1989).

More evidence of recent recruitment was noted in this reach of the Ohio River than during previous years (Figures 4 and 5). Good evidence of recruitment was noted in 1998 for Q. p. pustulosa (Figure 11), A. p. plicata (Figure 13), and O. reflexa. (Figure 14). However, the size demography of E. crassidens was similar in 1992, 1993, and 1998; during all years this population was composed of mainly old, large individuals. Elliptio crassidens requires the skipjack herring, Alosa chrysochloris, as the host fish for its glochidia (Fuller 1974). High-lift dams prevent annual upstream migrations by this fish species (Fuller 1974). Ten such dams, constructed during this century, occur between these study sites and the confluence of the Ohio River with the Mississippi River. It is likely that numbers of this species in the Ohio River have declined as a result of reduction of skipjack herring.

Demography of $Q . p$. pustulosa was virtually identical all study years, and showed good evidence of recent recruitment. This species, which uses some relatively common fish hosts (the black and brown bullhead, channel and flathead catfish, and white crappie (Fuller 1974)), has consistently shown substantial recent recruitment. This illustrates that for some species, conditions for successful recruitment are present.

Mean density of $C$. fluminea declined in this reach of the UOR during the study period (Figure 9). Convincing evidence was not found that this species competes with native mussels (Miller and Payne 1994). It was also noted that numbers of this species have declined in the lower Ohio River since the early 1980s (Payne and Miller 1994).

Mackie (1991) described impacts of $D$. polymorpha on Unionidae in Lake St. Clair during 1991. He noted that zebra mussels can affect the following activities of native species: normal burrowing and locomotion; balance and equilibrium; ability to close the shell; function of the siphons and therefore respiration and feeding; growth, reproduction, and feeding; food supplies; shell growth; and occlusion of the shell gape and ultimately smothering or death. Ricciardi, Whoriskey, and Rasmussen (1995) examined patterns of unionid infestations and predicted that severe unionid mortality, greater than 90 percent, occurs when $D$. polymorpha density is greater than 6,000 individuals $/ \mathrm{m}^{2}$ and 
more than 100 zebra mussels per unionid. These conditions do not currently exist in the UOR.

Although zebra mussels were collected in this reach of the UOR, their numbers are still too low to negatively affect the native species. Zebra mussels were first collected in the Illinois River in 1992 (Thiel, Blodgett, and Miller 1993). By 1993 density had increased dramatically; at RM 5.5 at Grafton, IL, values as high as $61,126 / \mathrm{m}^{2}$ were reported (Whitney, Blodgett, and Sparks 1995). However, by fall 1993, it was estimated that mortality at RM 5.5 and 66.8 was 22 percent and 41 percent, respectively. By late 1994 the investigators estimated that there had been a 99 percent reduction in zebra mussels at both RM 5.5 and 66.8. In 1995, investigators collected 34 1-m quadrats in the lower $193 \mathrm{~km}$ (120 miles) and found only 109 adult zebra mussels greater than $20 \mathrm{~mm}$ long (Whitney, Blodgett, and Sparks 1996).

The continued use of inland waterways to transport bulk commodities (Dietz et al. 1983) has caused planners and biologists in government agencies to express concern over the possible negative effects of commercial use of waterways on freshwater mussels. Quantitative and qualitative techniques are being used to obtain data on mussel density, relative species abundance, community composition, population demography, and presence of nonindigenous species. These parameters provide the most useful measures of the overall health and ultimate survival of a mussel community. They provide an opportunity to investigate the effects of complex, episodic events on a resource with ecological, economic, and cultural value.

Based upon information gathered in 1998, the condition at the mussel beds is good and is certainly no worse than in previous years. With respect to recent recruitment and continued existence of uncommon native species of freshwater mussels, it appears to be improving slightly. 


\section{References}

Branson, B. A., Harker, D. F., Baskin, J. M., Medley, M. E., Batch, D. L., Warren, M. L., Davis, W. H., Houtcooper, W. C., Monore, B., Phillippe, L. R., and Cupp, P. (1981). "Endangered, threatened, and rare animals and plants of Kentucky," Transactions of the Kentucky Academy of Sciences 42, 77-89.

Burch, J. B. (1975). Freshwater unionacean clams (Mollusca: Pelecypoda) of North America. Malacological Publications, Hamburg, MI.

Cummings, K., and Mayer, C. A. (1992). Field guide to freshwater mussels of the Midwest. Illinois Natural History Survey, Manual 5, Illinois Natural History Survey, Champaign, IL.

Dietz, A. R., Harrison, R. W., Olson, H. E., Grier, D., and C. Simpkins. (1983). "National waterways study--A framework for decision making--Final Report," Report NWS-83-1, U.S. Army Engineer Institute for Water Resources, Water Resources Support Center, Fort Belvoir, VA.

Fuller, S. L. H. (1974). "Clams and mussels (Mollusca:Bivalvia).” Pollution ecology of fresh water invertebrates. C. Hart and S. L. H. Fuller, ed., Academic Press, New York, 215-273.

Green, R. H. (1979). Sampling design and statistical methods for environmental biologists. John Wiley \& Sons, New York.

Hurlbert, S. H. (1984). "Pseudoreplication and the design of ecological field experiments," Ecological Monographs, 54, 187-211.

Isom, B. G., and Gooch, C. (1986). "Rationale and sampling design for fresh-water mussels, unionidae, in streams, large rivers, impoundments, and lakes." Rationale for sampling and interpretation of ecological data in the assessment of freshwater ecosystems. ASTM STP 894, B. G. Isom, ed., American Society for Testing and Materials, Philadelphia, PA, 46-59. 
Kovalak, W. P., Dennis, S. D., and Bates, J. M. (1986). "Sampling effort required to find rare species of freshwater mussels." Rationale for sampling and interpretation of ecological data in the assessment of freshwater ecosystems. ASTM STP 894, B. G. Isom, ed., American Society for Testing and Materials, Philadelphia, PA, 34-45.

Ludwig, J. A., and Reynolds, J. F. (1988). Statistical ecology; A primer on methods and computing. John Wiley \& Sons, New York.

Mackie, G. L. (1991). "Biology of the exotic zebra mussel, Dreissena polymorpha in relation to native bivalves and its potential to impact in Lake St. Clair," Hydrobiologia 219, 251-268.

McNaughton, S. J., and Wolf, L. L. (1973). General ecology. Holt, Rinehart, and Winston, New York.

Miller, A. C. (1988). "Mussel fauna associated with wing dams in Pool 7 of the upper Mississippi River," Freshwater Ecology 4, 299-302.

Miller, A. C., and Nelson, D. A. (1983). "An instruction report on freshwater mussels," Instruction Report El-83-2, U.S. Army Engineer Waterways Experiment Station, Vicksburg, MS.

Miller, A. C., and Payne, B. S. (1988). "The need for quantitative sampling to characterize size demography and density of freshwater mussel communities," American Malacological Bulletin 6, 49-54.

Miller, A. C., and Payne, B. S. (1993). "An analysis of freshwater mussels (Unionidae) in the upper Ohio River near Huntington, West Virginia; 1992 studies," Technical Report EL-93-27, U.S. Army Engineer Waterways Experiment Station, Vicksburg, MS.

Miller, A. C., and Payne, B. S. (1994). "Co-occurrence of native freshwater mussels (Unionidae) and the nonindigenous Corbicula fluminea at two stable shoals in the Ohio River," Malacological Review 27, 87-97.

Miller, A. C., and Payne, B. S. (1995). "An analysis of freshwater mussels (Unionidae) in the upper Ohio River near Huntington, West Virginia; 1993 studies," Technical Report EL-95-2, U.S. Army Engineer Waterways Experiment Station, Vicksburg, MS.

Miller, A. C., Payne, B. S., and Siemsen, T. (1986). "Description of the habitat of the endangered mussel, Plethobasus cooperianus," The Nautilus 100, 14-18.

Miller, A. C., Payne, B. S., and Tippit, R. (1992). "Characterization of a freshwater mussel community immediately downriver of Kentucky Lock and Dam in the Tennessee River," Transactions of the Kentucky Academy of Sciences 53, 154-161. 
Miller, A. C., Payne, B. S., Hornbach, D. J., and Ragland, D. V. (1990). "Physical effects of increased commercial navigation traffic in the Upper Mississippi River; Phase I studies," Technical Report EL-90-3, U.S. Army Engineer Waterways Experiment Station, Vicksburg, MS.

Miller, A. C., Payne, B. S., Shafer, D. S., and Neill, L. T. (1993). "Techniques for monitoring bivalve communities and populations in large rivers." Conservation and management of freshwater mussels, Proceedings of an Upper Mississippi River Conservation Committee symposium, St. Louis, MO, 12-14 October 1992. K. S. Cummings, A. C. Buchanan, and L. M. Koch, ed., Rock Island, IL, 147-158.

Parmalee, P. W., and Bogan, A. E. (1998). The freshwater mussels of Tennessee. The University of Tennessee Press, Knoxville, TN.

Payne, B. S., and Miller, A. C. (1994). "Freshwater mussels at two beds in the lower Ohio River near Olmsted, Illinois; 1992 studies," Technical Report EL-94-2, U.S. Army Engineer Waterways Experiment Station, Vicksburg, MS.

Payne, B. S., and Miller, Andrew C. (1997). "Spatial distribution of mussels at a bed in the lower Ohio River near Olmsted, Illinois," Technical Report EL-97-3, U.S. Army Engineer Waterways Experiment Station, Vicksburg, MS.

Payne, B. S., Miller, A. C., and Aldridge, D. W. (1987). "Environmental effects of navigation traffic: Laboratory studies of the effects on mussels of intermittent exposure to turbulence and suspended solids," Technical Report EL-87-14, U.S. Army Engineer Waterways Experiment Station, Vicksburg, MS.

Ricciardi, A., Whoriskey, F. G., and Rasmussen, J. B. (1995). "Predicting the intensity and impact of Dreissena infestation on native unionid bivalves from Dreissena field density," Canadian Journal of Fisheries and Aquatic Sciences 52, 1449-1461.

Shannon, C. E., and Weaver, W. (1949). The mathematical theory of communication. University of Illinois Press, Urbana IL.

Taylor, L. R. (1987). “Objective and experiment in long-term research.” Longterm studies in ecology. G. E. Likens, ed., Springer-Verlag, New York, 20-70.

Thiel, P. A., Blodgett, K. D., and Miller, A. C. (1993). "Zebra mussel invasion of the Illinois and Mississippi Rivers," Dreissena polymorpha Information Review 4(1), 1. 
Tolin, W. A., Schmidt, J., and Zeto, M. (1987). "A new location for the Federally-listed endangered unionid Lampsilis abrupta (Say 1821) (=Lampsilis orbiculata (Hildreth 1828)), the pink mucket, in the upper Ohio River bordering West Virginia," Malacology Data Net 2, 18.

U.S. Fish and Wildlife Service. (1991). "Endangered and threatened wildlife and plants," Federal Register, July 15, 1991. 50 CFR 17.11 \& 17.12.

Way, C. M., Miller, A. C., and Payne, B. S. (1989). "The influence of physical factors on the distribution and abundance of freshwater mussels (Bivalvia: Unionidae) in the lower Tennessee River," The Nautilus 103, 96-98.

Whitney, S. D., Blodgett, K. D., and Sparks, R. E. (1995). “Update on zebra mussels and native unionids in the Illinois River," Illinois Natural History Survey, Zebra Mussel Research Team, January, 1.

Whitney, S. D., Blodgett, K. D., and Sparks, R. E. (1996). "Update on zebra mussels and native unionids in the Illinois River; Part III," Illinois Natural History Survey, Zebra Mussel Research Team, April, 1.

Williams, J. D., Warren, M. L., Jr., Cummins, K. S., Harris, J. L., and R. J. Neves. (1993). "Conservation status of freshwater mussels of the United States and Canada," Fisheries 18(9), 6-22. 


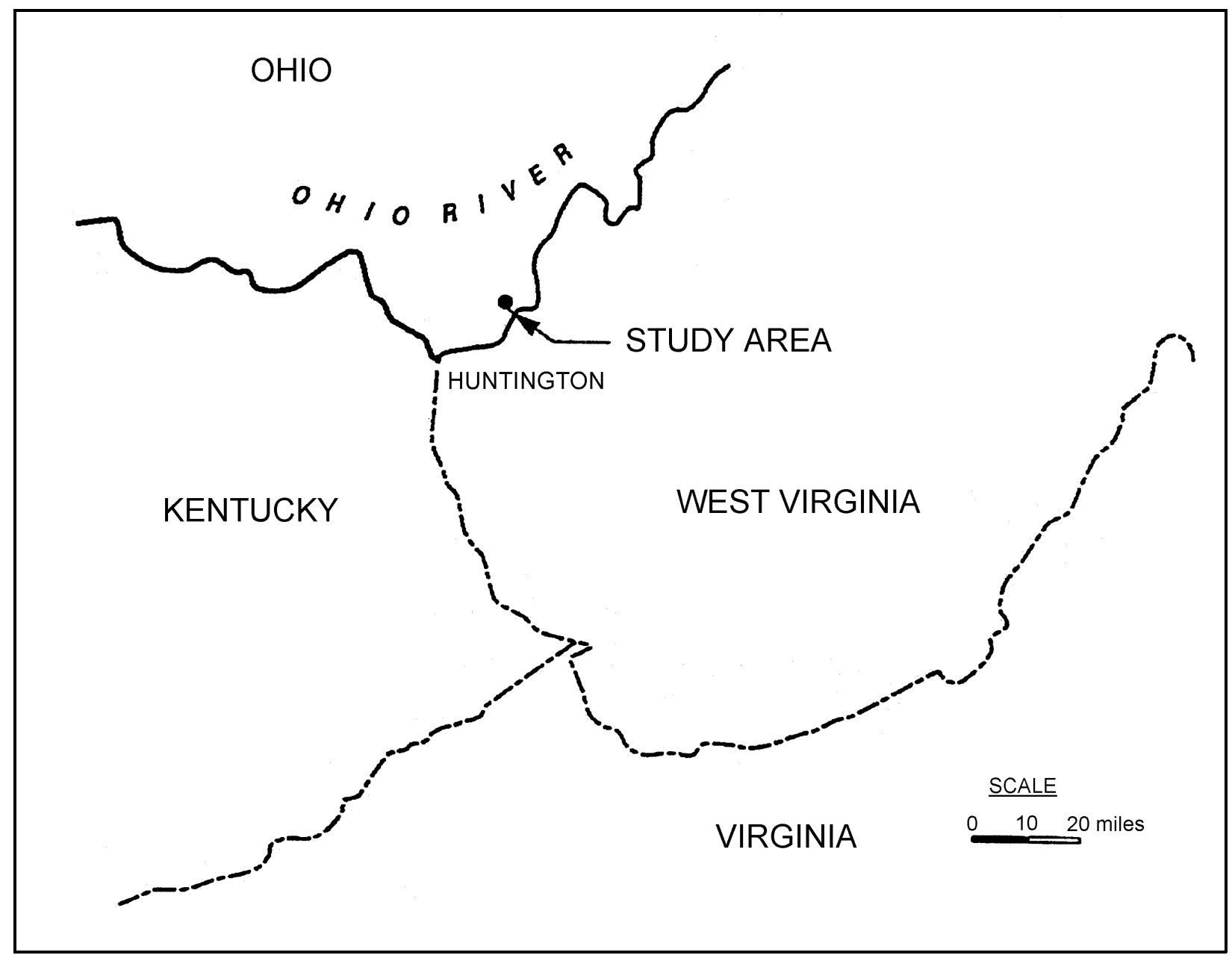

Figure 1. The study area in the upper Ohio River (to convert miles to kilometers, multiply by 1.609) 


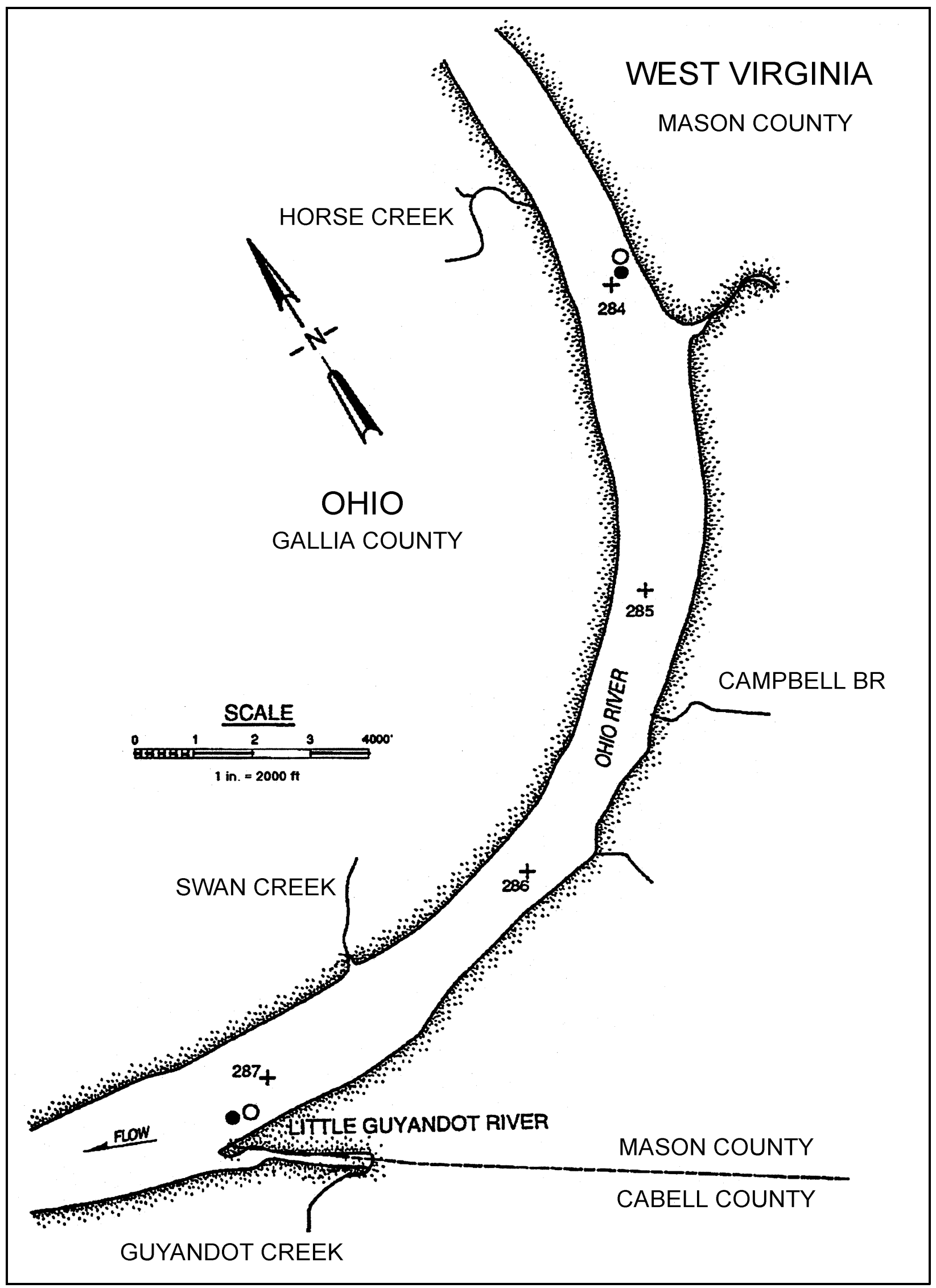

Figure 2. Sample sites located between RM 287 and 284 in the upper Ohio River, 1998 (to convert inches to millimeters, multiply by 25.4 ; to convert feet to meters, multiply by 0.3048 ) 


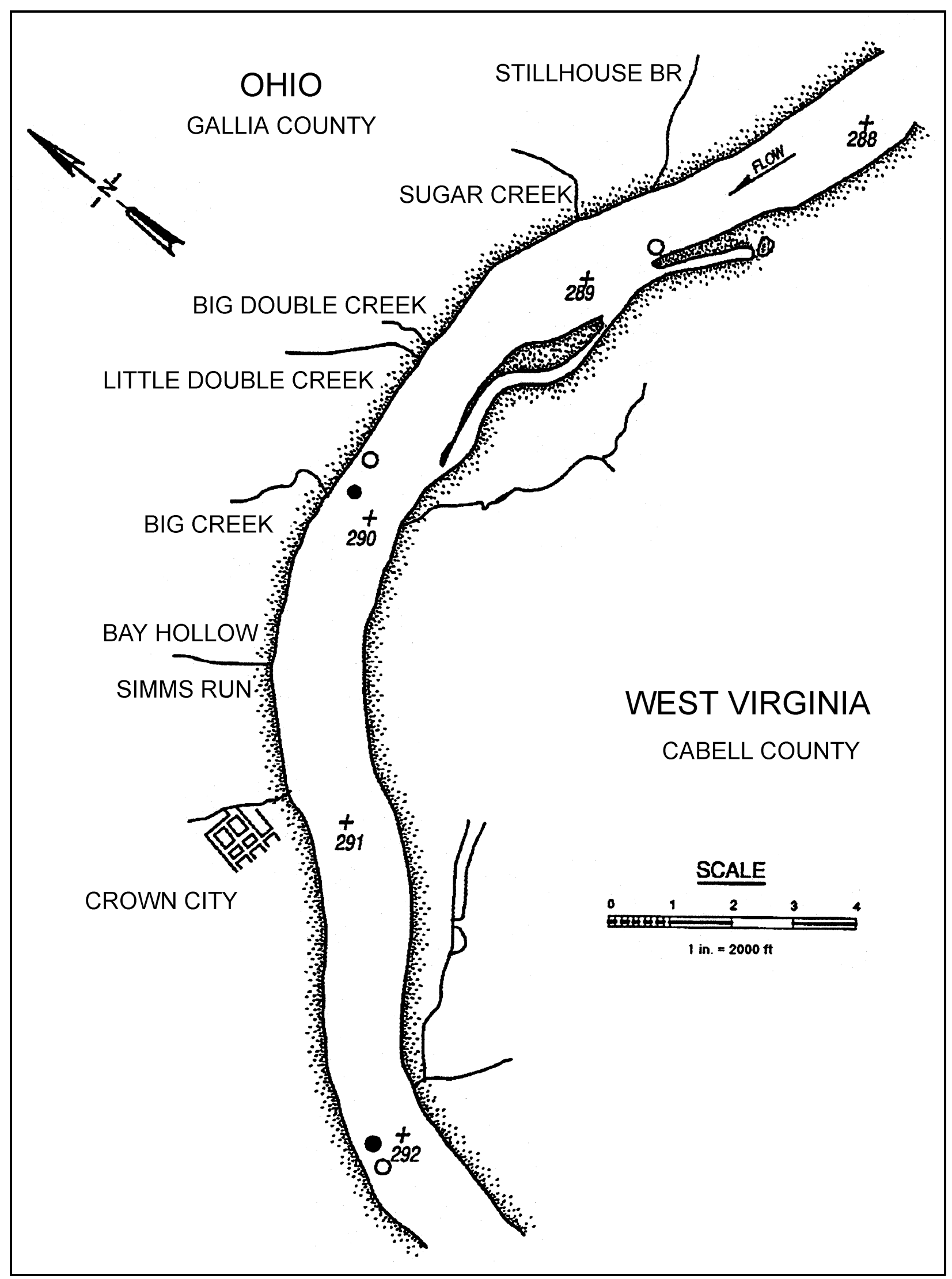

Figure 3. Sample sites located between RM 292 and 288 in the upper Ohio River, 1998 


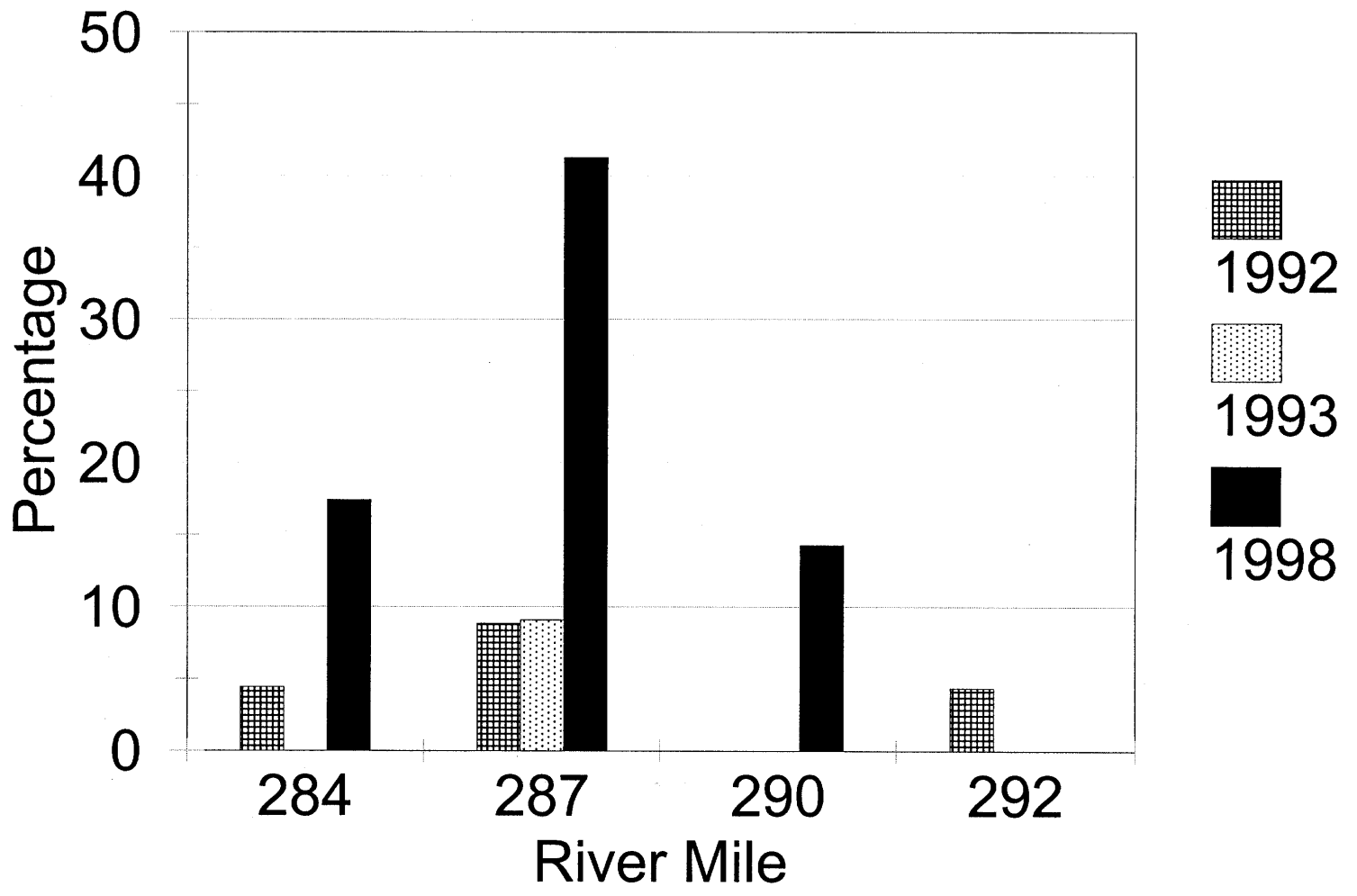

Figure 4. Evidence of recent mussel recruitment, percent individuals less than $30 \mathrm{~mm}$ total shell length 


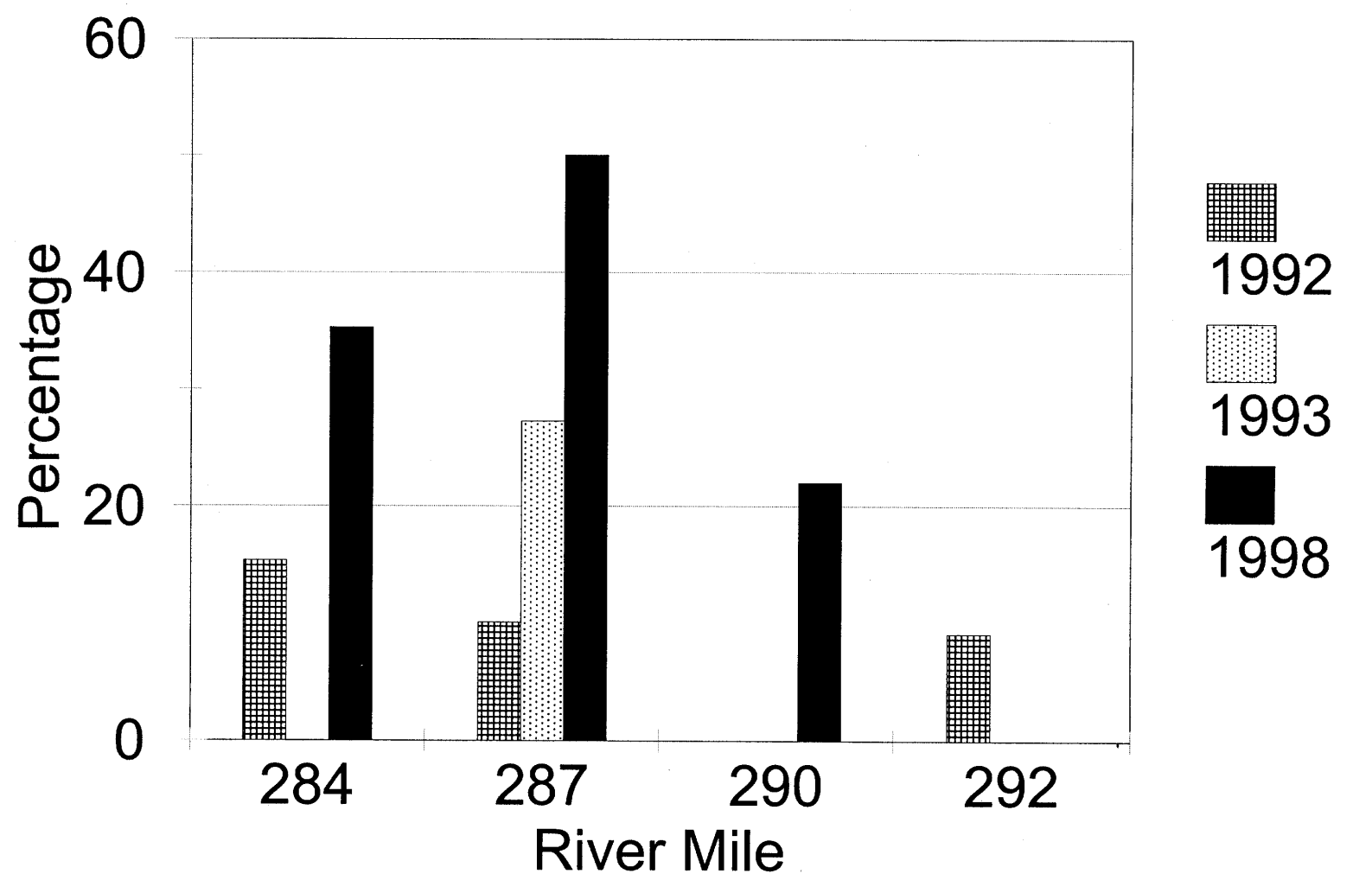

Figure 5. Evidence of recent mussel recruitment, percent species less than $30 \mathrm{~mm}$ total shell length

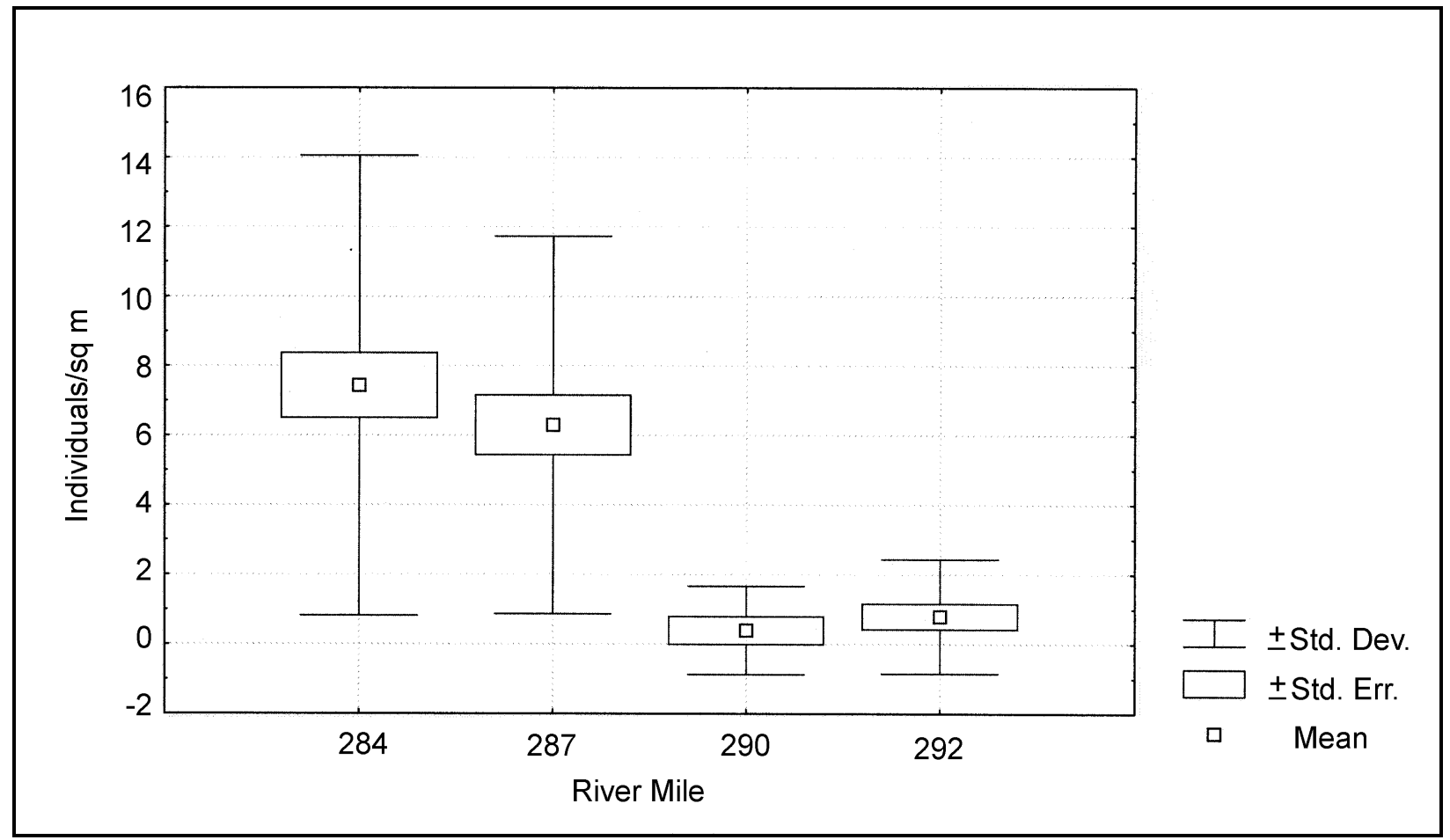

Figure 6. Mean unionid density at four mussel beds in the upper Ohio River, 1998 


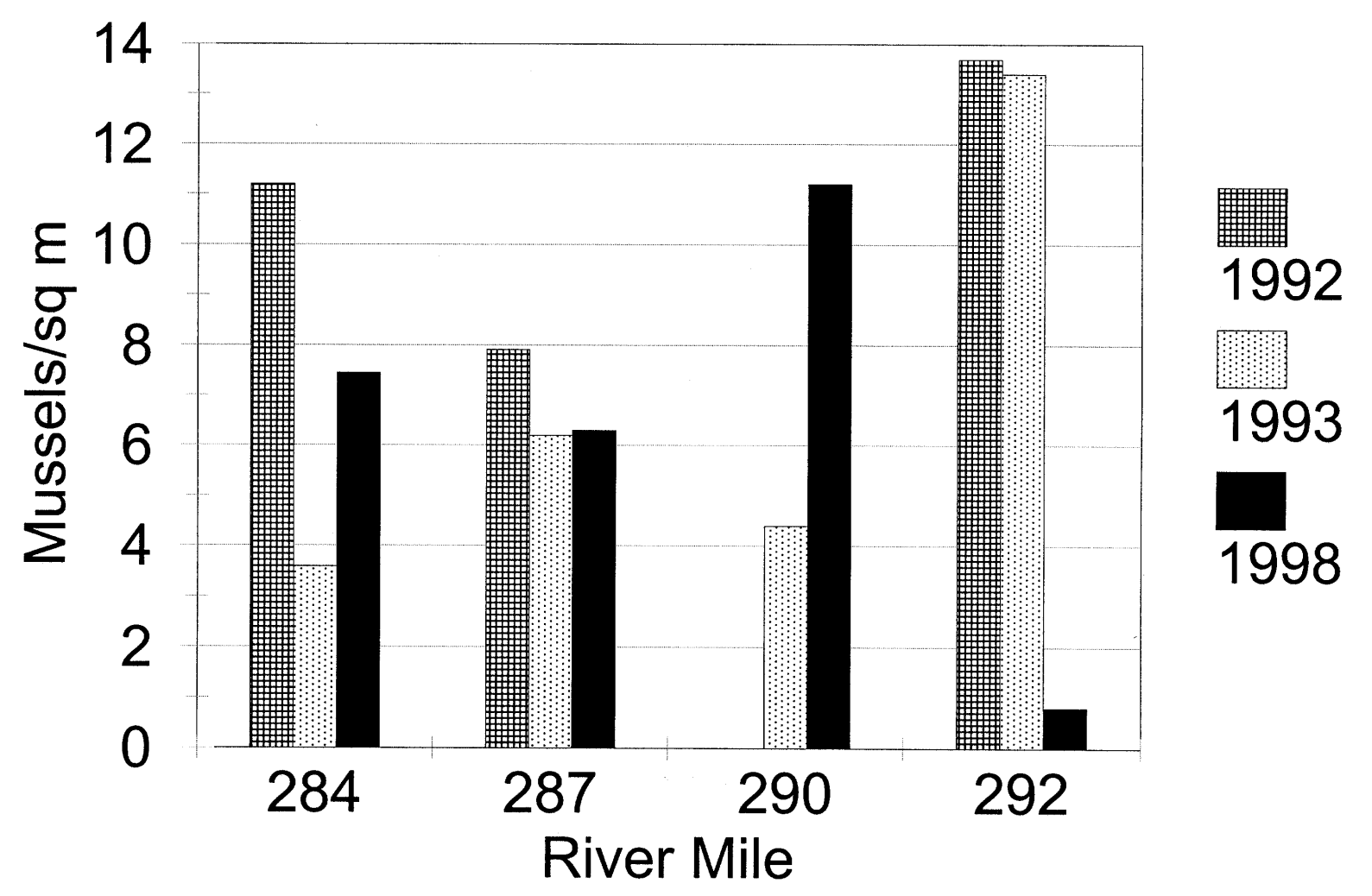

Figure 7. Mean unionid density, 1992, 1993, and 1998, at four locations in the upper Ohio River

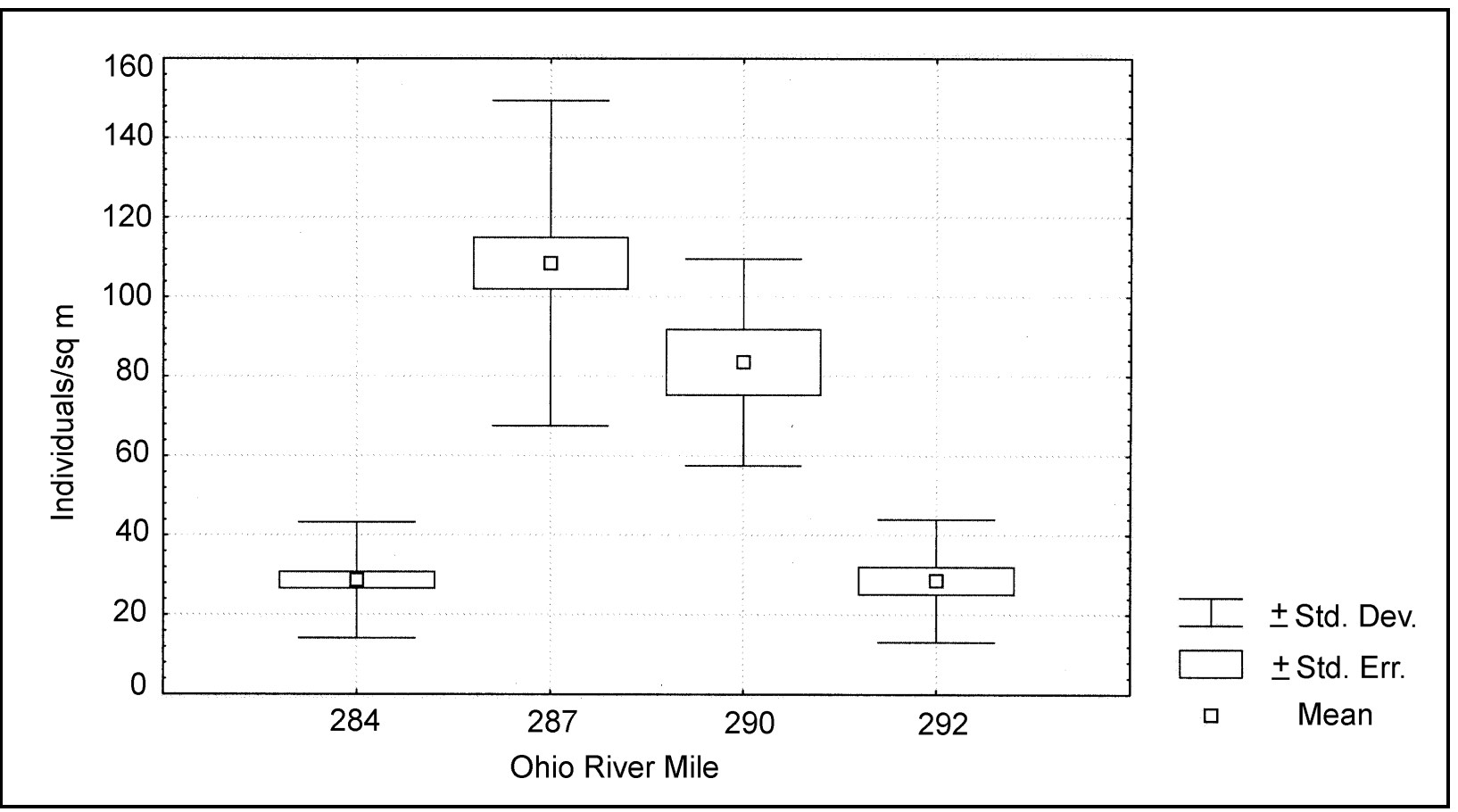

Figure 8. Mean density of the Asian clam C. fluminea at four locations in the upper Ohio River, 1998 


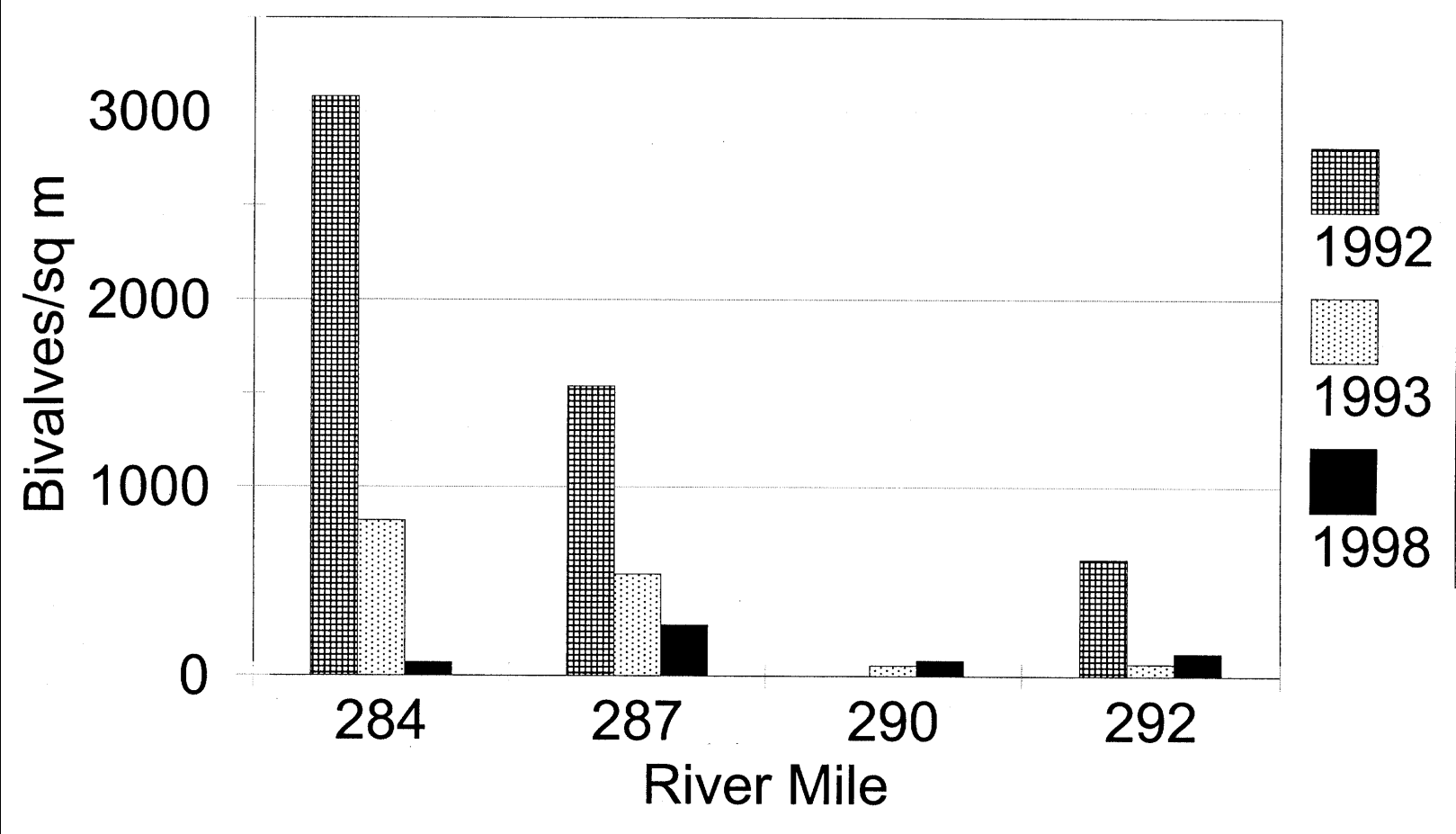

Figure 9. Mean C. fluminea density, 1992, 1993, and 1998, at four locations in the upper Ohio River

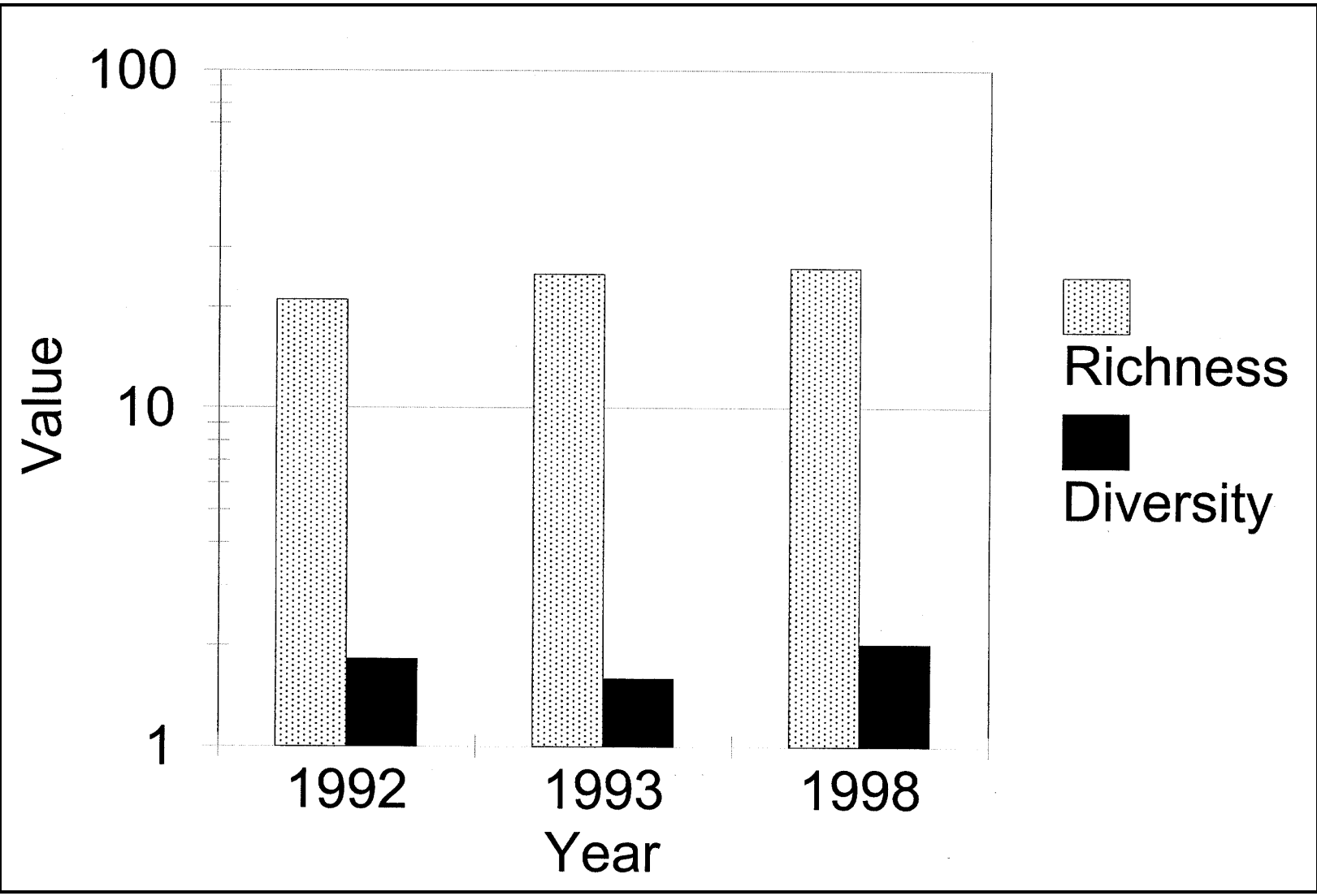

Figure 10. Changes in species richness and species diversity, all sites combined, qualitative samples only, upper Ohio River for years 1992, 1993, and 1998 


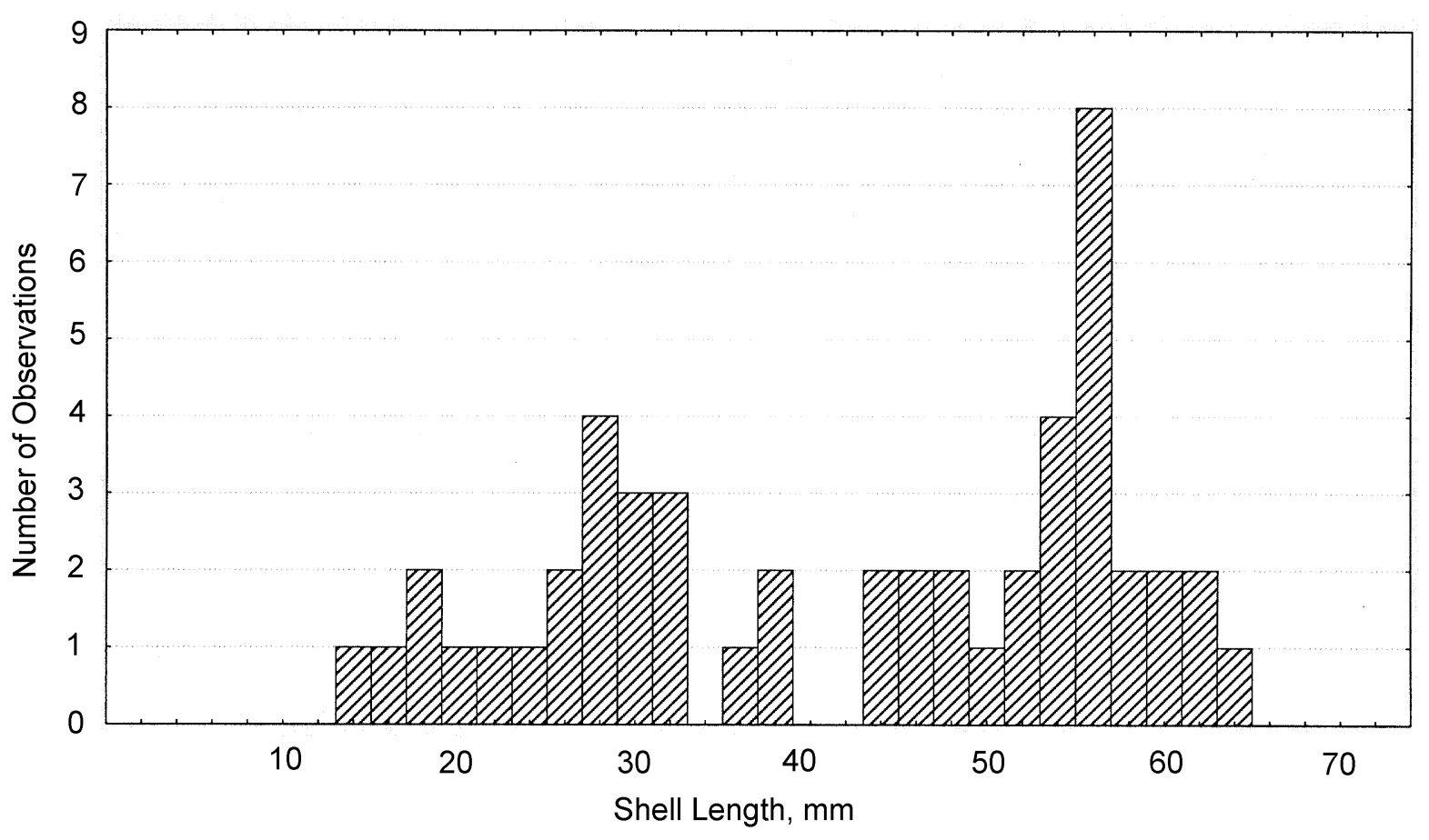

Figure 11. Size demography for Q. p. pustulosa, all locations combined, in the upper Ohio River, 1998

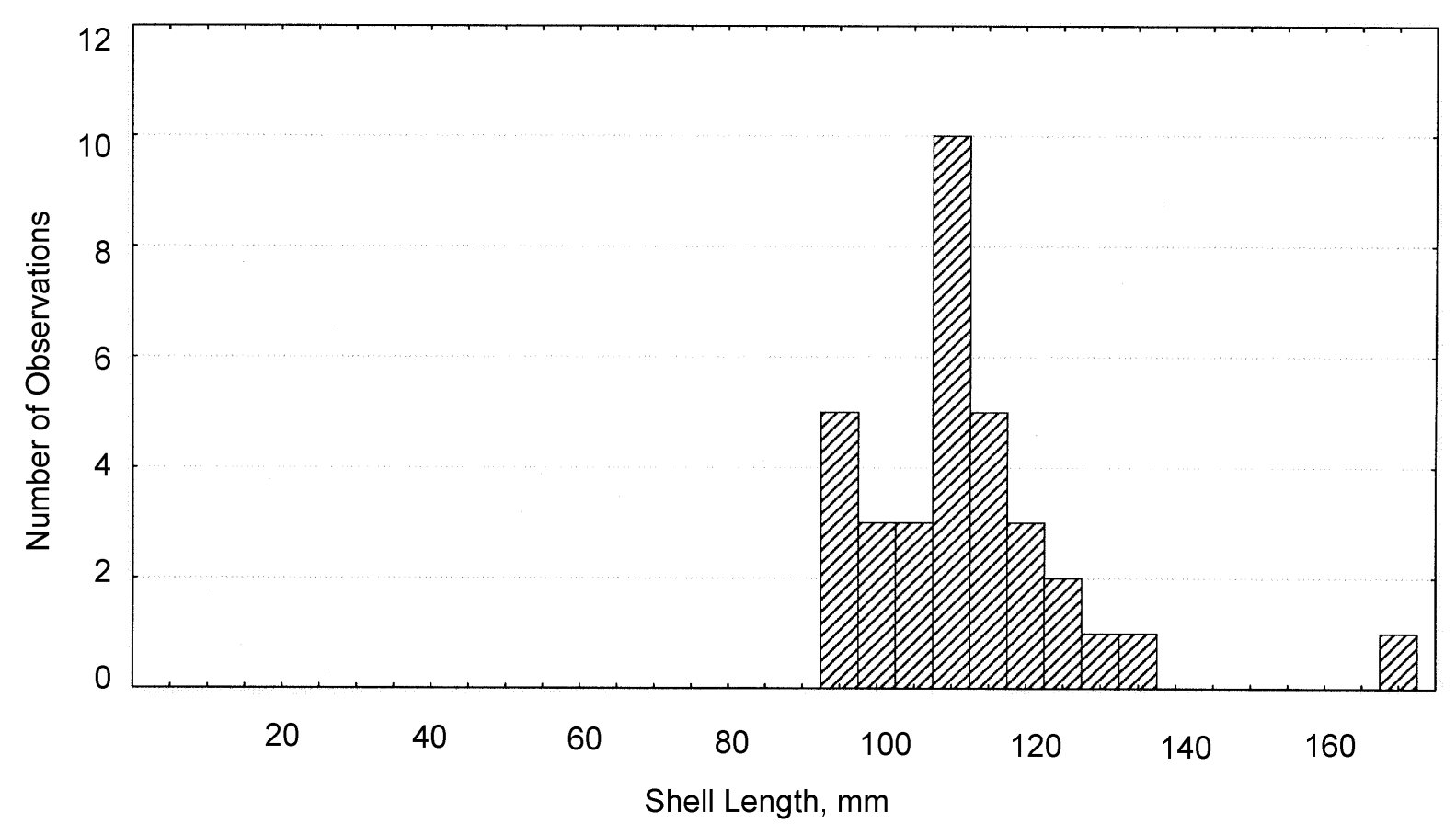

Figure 12. Size demography for E. crassidens, all locations combined, in the upper Ohio River, 1998 


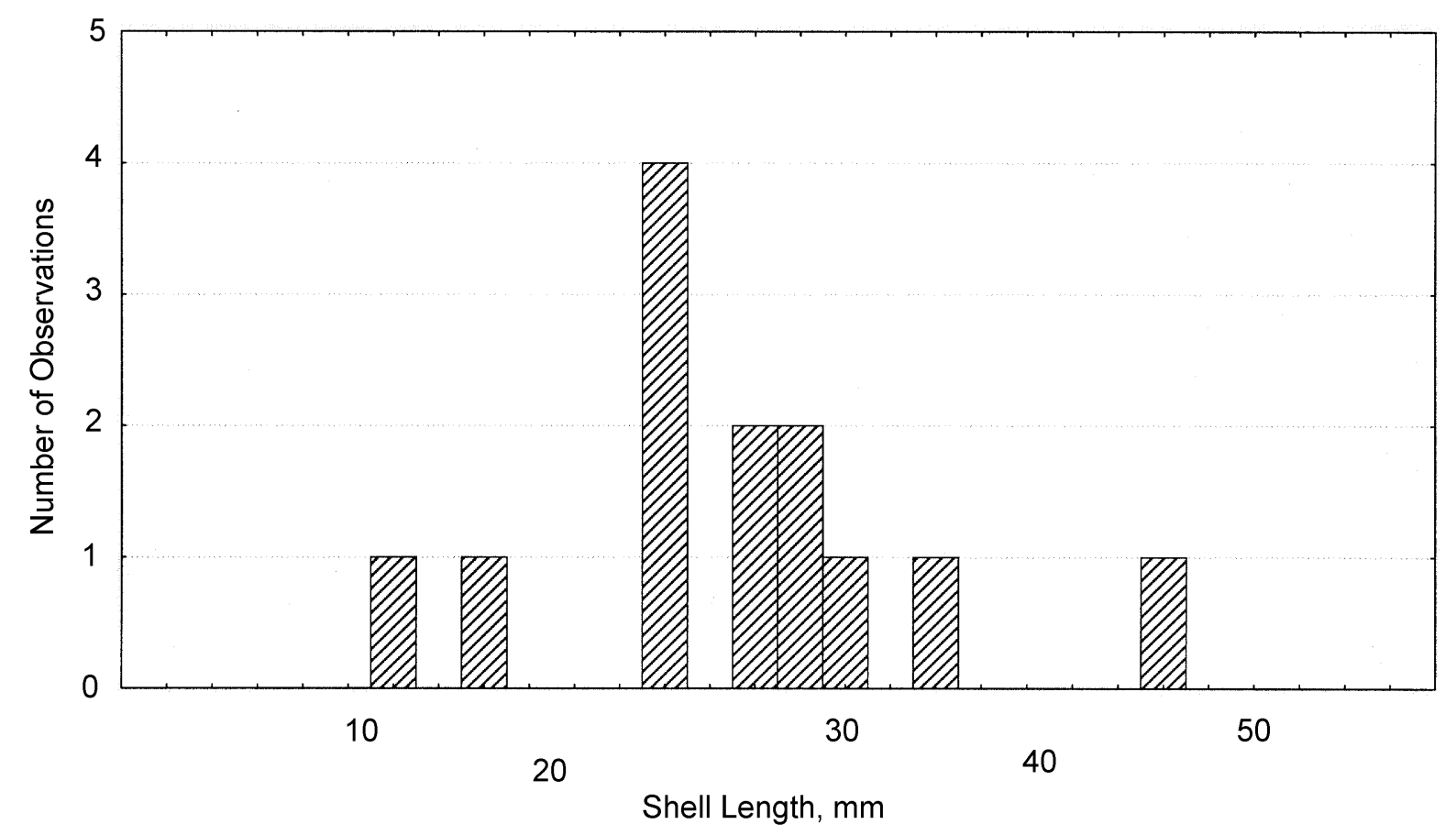

Figure 13. Size demography for A. p. plicata, all locations combined, in the upper Ohio River, 1998

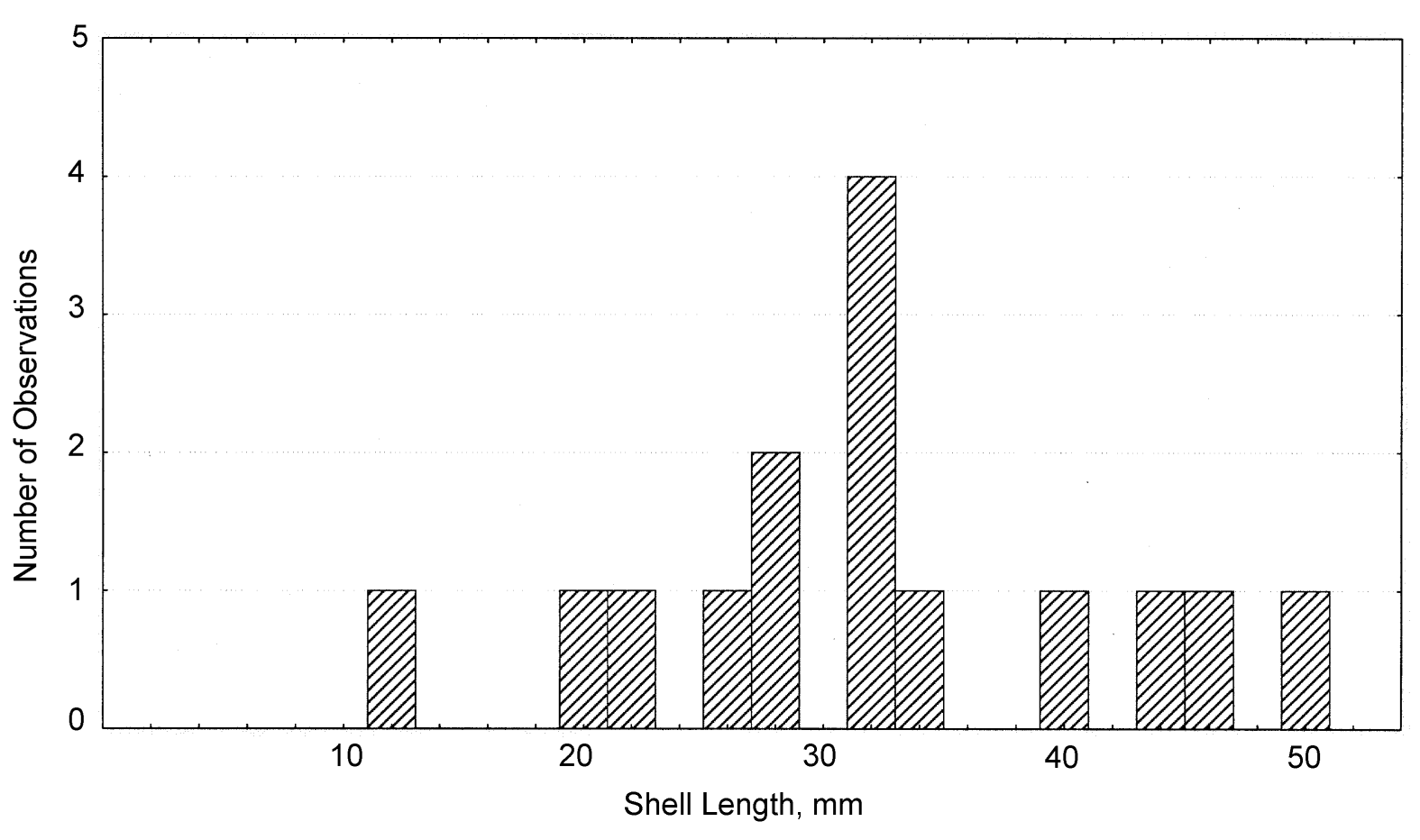

Figure 14. Size demography for O. reflexa, all locations combined, in the upper Ohio River, 1998 


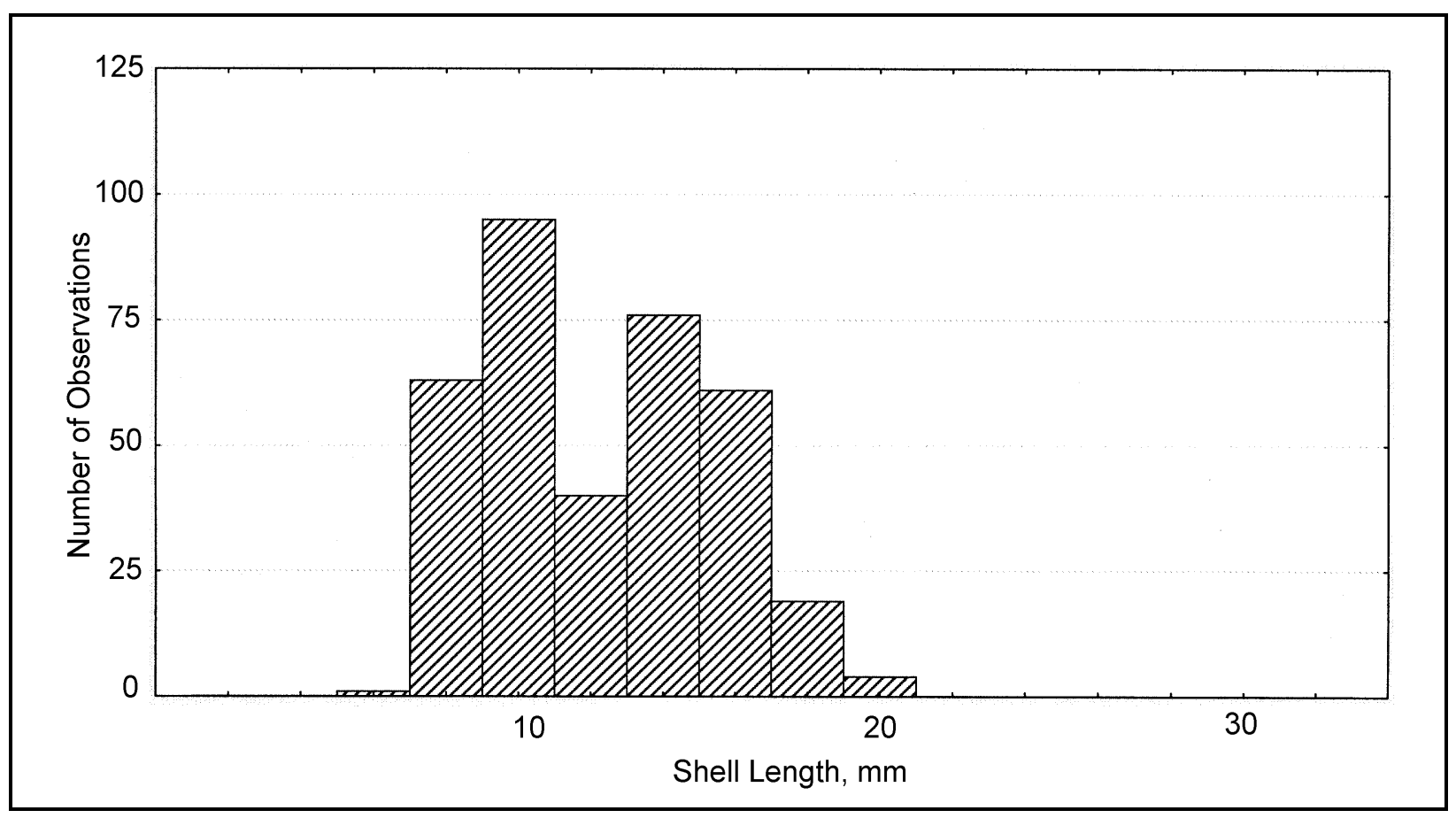

Figure 15. Size demography for C. fluminea at upper Ohio River Mile 284, 1998

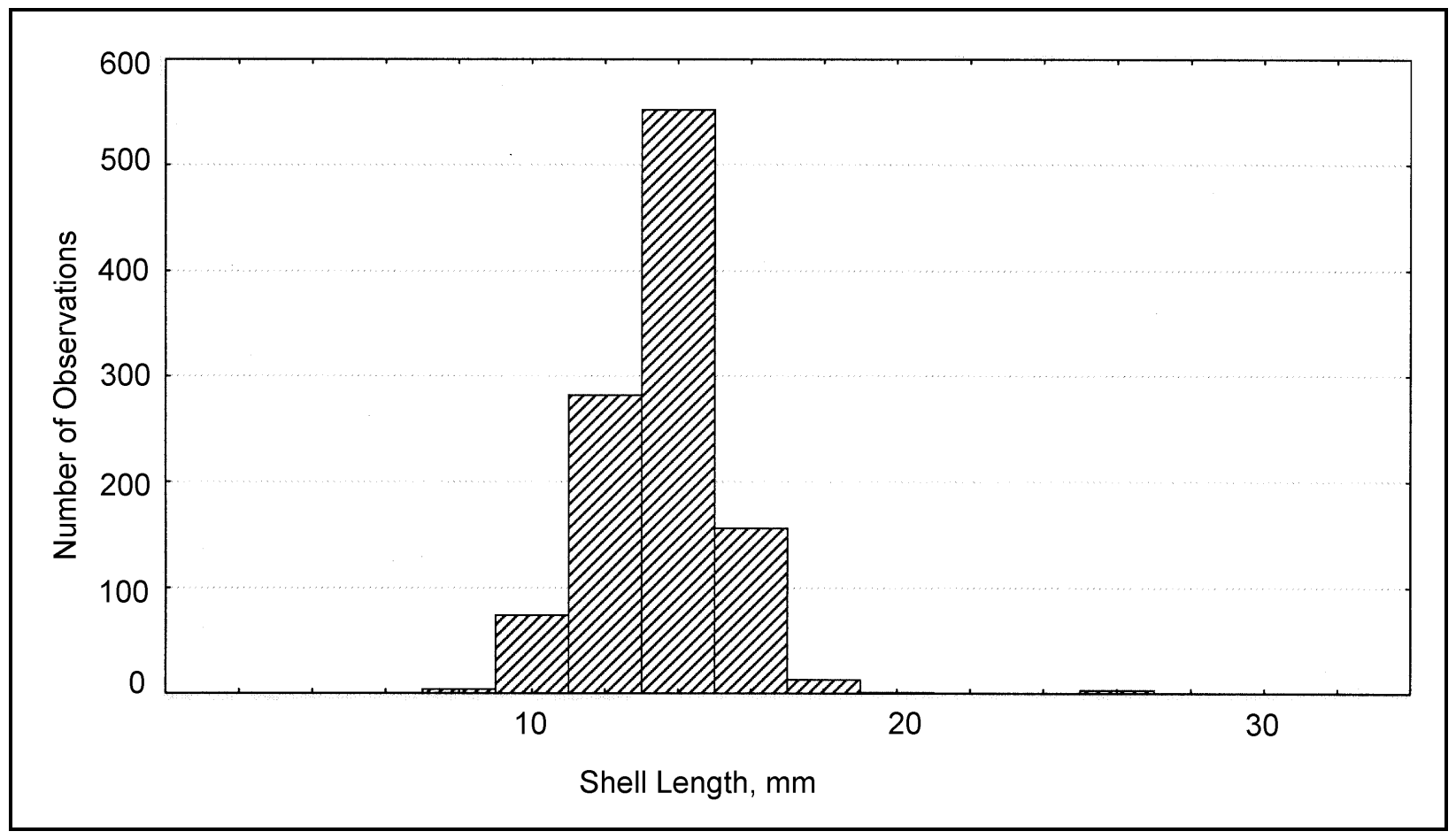

Figure 16. Size demography for C. fluminea at upper Ohio River Mile 287, 1998 


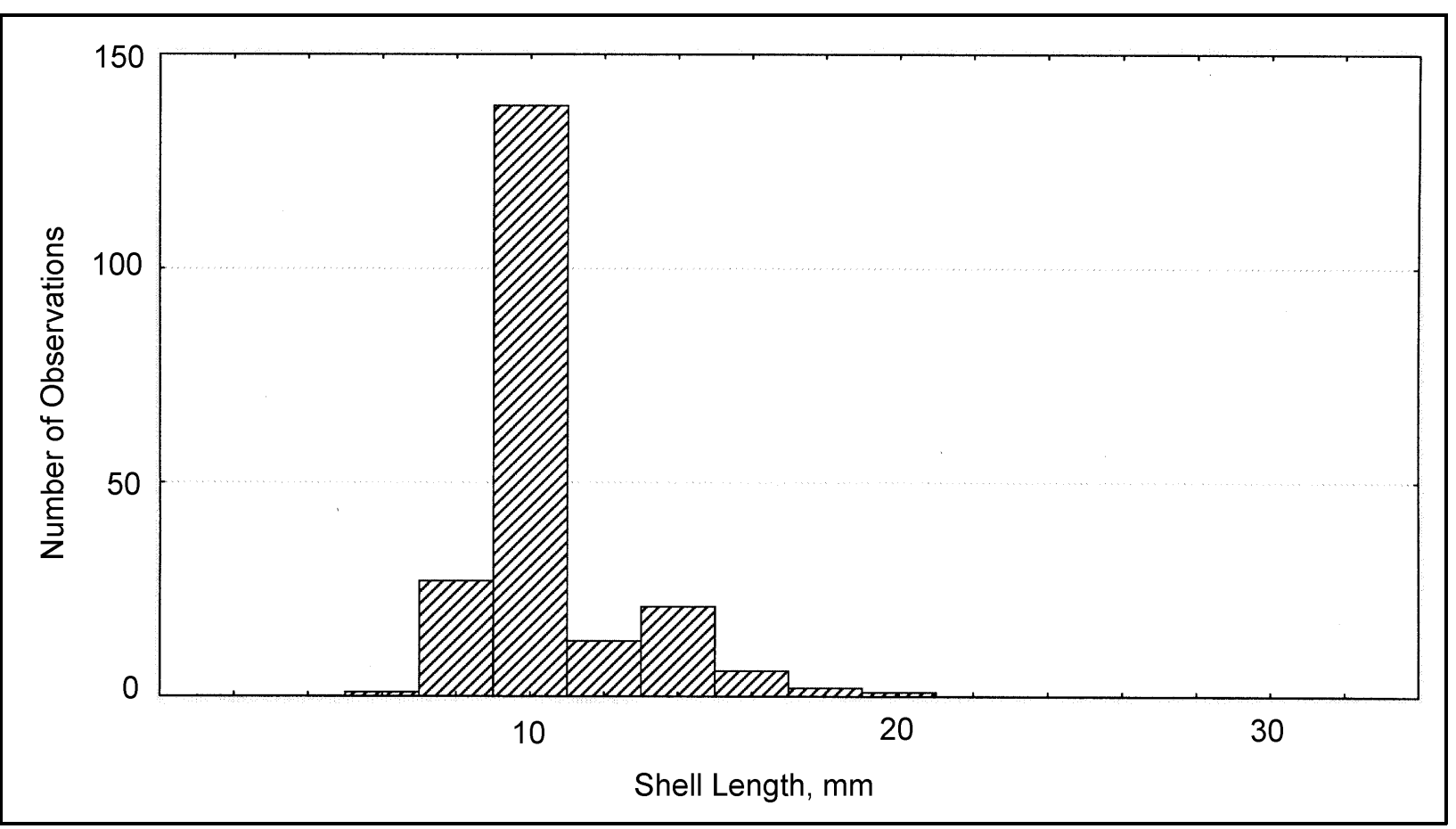

Figure 17. Size demography for C. fluminea at upper Ohio River Mile 290, 1998

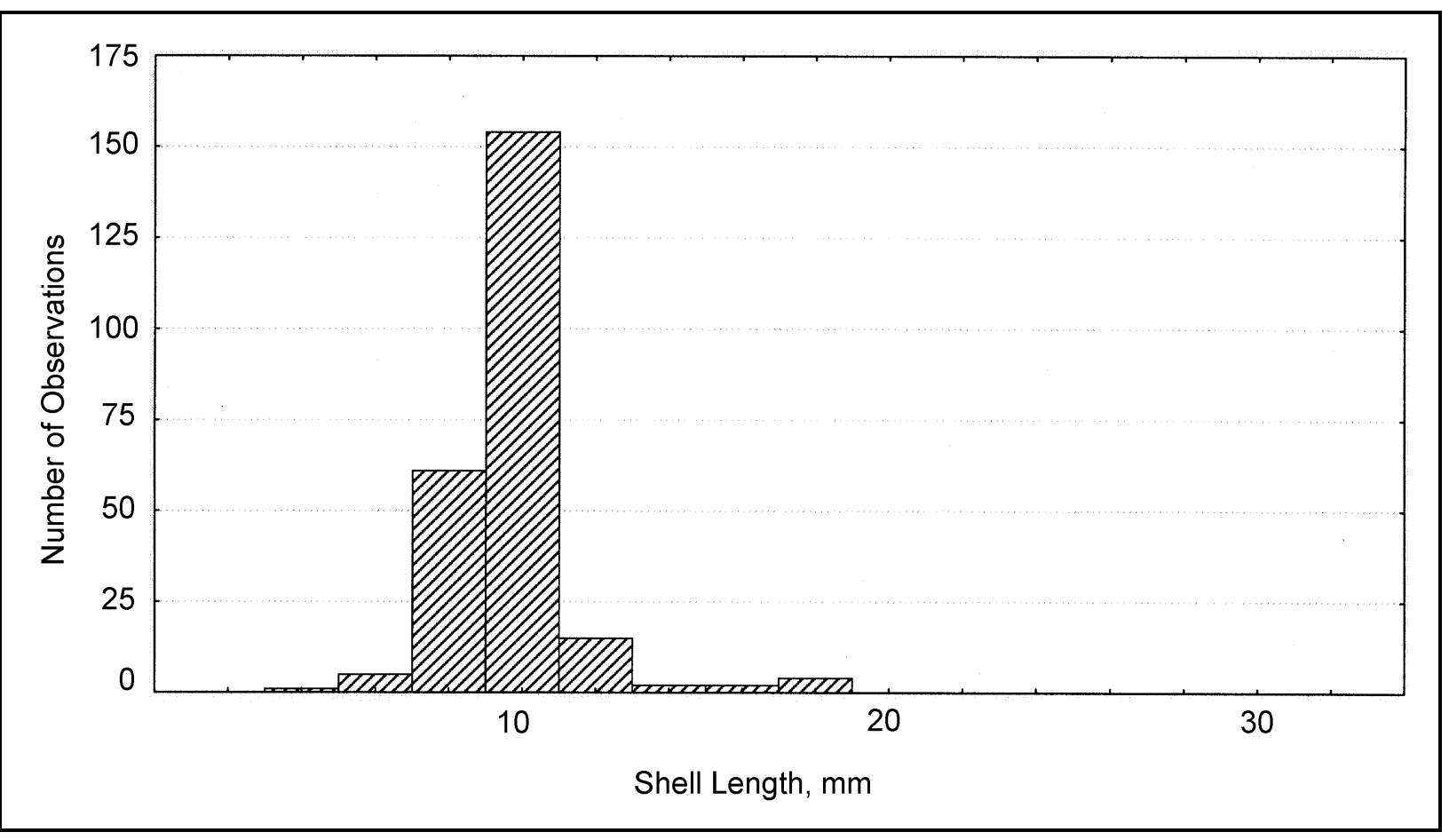

Figure 18. Size demography for C. fluminea at upper Ohio River Mile 292, 1998 


\begin{tabular}{|c|c|c|c|c|c|c|c|}
\hline \multicolumn{8}{|c|}{$\begin{array}{l}\text { Table } 1 \\
\text { Location and Number of Samples Collected Using Qualitative and Quantitative } \\
\text { Methods in the Upper Ohio River, September 1998, } 61 \mathrm{~m}(200 \mathrm{ft}) \mathrm{from} \text { Shore, Depth of } \\
\text { Water 3.7-7.6 m (12-25 ft) }\end{array}$} \\
\hline \multirow[b]{2}{*}{ Date } & \multirow[b]{2}{*}{$\begin{array}{l}\text { Approx. } \\
\text { River Mile }\end{array}$} & \multirow{2}{*}{$\begin{array}{l}\text { Global } \\
\text { Positioning } \\
\text { System }\end{array}$} & \multirow[b]{2}{*}{ Bank $^{1}$} & \multicolumn{2}{|c|}{ Qualitative } & \multicolumn{2}{|c|}{ Quantiative } \\
\hline & & & & No. of Sites & Total & $\begin{array}{l}\text { No. of } \\
\text { Subsites }\end{array}$ & $\begin{array}{l}\text { No. of } \\
\text { Samples }\end{array}$ \\
\hline $18 \mathrm{Sep}$ & 287 & $\begin{array}{l}38 \circ 35.302 \\
82 \circ 12.677\end{array}$ & $\mathrm{RDB}$ & 2 & 24 & 4 & 40 \\
\hline 19 Sep & 292 & $\begin{array}{l}38 \circ 25.210 \\
82 \circ 12.811\end{array}$ & $\mathrm{RDB}$ & & & 2 & 20 \\
\hline 19 Sep & 290 & $\begin{array}{l}38 \circ 35.913 \\
82 \circ 15.592\end{array}$ & $\mathrm{RDB}$ & 1 & 12 & 1 & 10 \\
\hline 20 Sep & 284 & \multirow{3}{*}{$\begin{array}{l}38 \circ 36.703 \\
82 \circ 10.249\end{array}$} & LDB & & & 2 & 20 \\
\hline 20 Sep & 284 & & LDB & 2 & 24 & 1 & 10 \\
\hline $21 \mathrm{Sep}$ & 284 & & LDB & 2 & 24 & 2 & 20 \\
\hline \multicolumn{5}{|c|}{ Total Samples } & 84 & & 120 \\
\hline
\end{tabular}




\begin{tabular}{|c|c|c|c|c|c|c|c|}
\hline \multicolumn{8}{|c|}{$\begin{array}{l}\text { Table } 2 \\
\text { Species of Freshwater Mussels Collected in the upper Ohio River, 1992, 1993, and } \\
1998\end{array}$} \\
\hline \multirow[b]{2}{*}{ Scientific Name } & \multirow[b]{2}{*}{ Common Name } & \multicolumn{2}{|c|}{1992} & \multicolumn{2}{|c|}{1993} & \multicolumn{2}{|c|}{1999} \\
\hline & & Qual & Quant & Qual & Quant & Qual & Quant \\
\hline Actinonaias ligamentina & Mucket & $x$ & $\mathrm{X}$ & $x$ & $x$ & $x$ & $x$ \\
\hline Amblema plicata plicata & Threeridge & $x$ & $x$ & $x$ & $x$ & $x$ & $x$ \\
\hline Ellipsaria lineolata & Butterfly & $\mathrm{x}$ & $\mathrm{x}$ & $x$ & $x$ & $x$ & $x$ \\
\hline Elliptio crassidens & Elephant ear & $\mathrm{x}$ & $\mathrm{x}$ & $x$ & $x$ & $x$ & $x$ \\
\hline Elliptio dilatata & Spike & & & & & $x$ & \\
\hline Fusconaia ebena & Ebony shell & $x$ & $x$ & $x$ & $x$ & $x$ & $x$ \\
\hline Fusconaia flava & Wabash pigtoe & & & $x$ & $x$ & & \\
\hline Fusconaia subrotunda & Long-solid & $x$ & & $x$ & & $x$ & \\
\hline Lampsilis abrupta & Pink mucket & & & $x$ & & & \\
\hline Lampsilis cardium & Pocketbook & $x$ & $x$ & $x$ & $x$ & $x$ & $x$ \\
\hline Lampsilis siliquoidea & Fatmucket & & & & & $x$ & \\
\hline Lampsilis teres & Yellow sandshell & & & & & & $x$ \\
\hline Lasmigonia complanata & White heelsplitter & & & $x$ & & & $x$ \\
\hline Lasmigonia costata & Fluted shell & & & $x$ & $x$ & $x$ & \\
\hline Leptodea fragilis & Fragile papershell & $x$ & & $x$ & & $x$ & $x$ \\
\hline Ligumia recta & Black sandshell & $x$ & $x$ & $x$ & & $x$ & $x$ \\
\hline Megalonaias nervosa & Washboard & $x$ & $x$ & $x$ & & $x$ & $x$ \\
\hline Obovaria reflexa & Threehorn wartyback & $x$ & $x$ & $x$ & $x$ & $x$ & $x$ \\
\hline Obovaria retusa & Ring pink & & $x$ & & & & \\
\hline Obovaria subrotunda & Round hickorynut & & & $x$ & & $x$ & \\
\hline Plethobasus cyphyus & Sheepnose & $x$ & $x$ & $x$ & & $x$ & \\
\hline Pleurobema coccineum & Round pigtoe & $x$ & & $x$ & & $x$ & \\
\hline Pleurobema cordatum & Ohio pigtoe & $x$ & $x$ & $x$ & $x$ & $x$ & $x$ \\
\hline Potamilus alatus & Pink heelsplitter & $x$ & $x$ & $x$ & $x$ & $x$ & $x$ \\
\hline Quadrula metanevra & Monkeyface & $x$ & $x$ & $x$ & $x$ & $x$ & $x$ \\
\hline Quadrula nodulata & Wartyback & & & $x$ & & & \\
\hline Quadrula pustulosa pustulosa & Pimpleback & $x$ & $x$ & $x$ & $x$ & $x$ & $x$ \\
\hline Quadrula quadrula & Mapleleaf & $x$ & $x$ & $x$ & $x$ & $x$ & $x$ \\
\hline Truncilla truncata & Deertoe & $x$ & $x$ & & $x$ & & $x$ \\
\hline Truncilla donaciformis & Fawnsfoot & $x$ & & & & & $x$ \\
\hline & Total species & 20 & 17 & 24 & 15 & 22 & 19 \\
\hline & Total individuals & 1477 & 328 & 4700 & 191 & 1279 & 188 \\
\hline & Total sites & 5 & 4 & 25 & 4 & 3 & 3 \\
\hline & Total samples & 97 & 120 & 293 & 118 & 84 & 120 \\
\hline
\end{tabular}




\begin{tabular}{|c|c|c|}
\hline \multicolumn{3}{|c|}{$\begin{array}{l}\text { Table } 3 \\
\text { Percent Abundance and Frequency of Occurrence of Unionid Species Collected in the } \\
\text { Upper Ohio River, September } 1998 \text { (All individuals were collected using quantitative } \\
\text { methods) }\end{array}$} \\
\hline Species & Percent Abundance & Frequency of Occurrence \\
\hline Q.p.pustulosa & 26.60 & 29.17 \\
\hline E. crassidens & 18.09 & 22.50 \\
\hline O. reflexa & 15.43 & 22.50 \\
\hline A. p. plicata & 6.91 & 9.17 \\
\hline E. lineolata & 6.38 & 10.00 \\
\hline A. ligamentina & 4.26 & 5.00 \\
\hline Q. metanevra & 3.19 & 5.00 \\
\hline P. alatus & 3.19 & 11.67 \\
\hline L. recta & 2.66 & 4.17 \\
\hline T. truncata & 2.66 & 3.33 \\
\hline P. cordatum & 2.13 & 10.00 \\
\hline Q. quadrula & 1.60 & 2.50 \\
\hline L. fragilis & 1.60 & 2.50 \\
\hline L. cardium & 1.06 & 1.67 \\
\hline T. donaciformis & 1.06 & 2.50 \\
\hline F. ebena & 1.06 & 1.67 \\
\hline M. nervosa & 1.06 & 1.67 \\
\hline L. complanata & 0.53 & 0.83 \\
\hline L. teres & 0.53 & 0.83 \\
\hline
\end{tabular}




\begin{tabular}{|c|c|c|c|c|c|c|c|c|}
\hline \multirow{3}{*}{\begin{tabular}{||l} 
Table 4 \\
Summary Inforn \\
September 1998 \\
Species
\end{tabular}} & n on Fr & hwate & Mussel & Collec & in $Q$ & litative & ollect & \\
\hline & \multicolumn{2}{|c|}{ RM 287} & \multicolumn{2}{|c|}{ RM 290} & \multicolumn{2}{|c|}{ RM 284} & \multicolumn{2}{|c|}{ Total } \\
\hline & $\%$ Abun & $\%$ Occur & $\%$ Abun & $\%$ Occur & $\%$ Abun & $\%$ Occur & $\%$ Abun & $\%$ Occur \\
\hline Elliptio crassidens & 38.32 & 83.33 & 29.35 & 83.33 & 50.89 & 100.00 & 44.18 & 92.86 \\
\hline $\begin{array}{l}\text { Quadrula pustulosa } \\
\text { pustulosa }\end{array}$ & 13.59 & 83.33 & 29.89 & 100.00 & 9.77 & 75.00 & 13.76 & 80.95 \\
\hline Quadrula metanevra & 8.70 & 54.17 & 10.33 & 75.00 & 9.63 & 72.92 & 9.46 & 67.86 \\
\hline Pleurobema cordatum & 11.14 & 75.00 & 6.52 & 58.33 & 3.58 & 41.67 & 6.18 & 53.57 \\
\hline Actinonaias ligamentina & 2.72 & 33.33 & 1.09 & 8.33 & 8.12 & 70.83 & 5.55 & 51.19 \\
\hline Potamilus alatus & 3.26 & 33.33 & 2.17 & 16.67 & 4.95 & 48.92 & 4.07 & 39.29 \\
\hline Elliptio dilatata & 10.05 & 12.50 & 0.00 & 0.00 & 0.00 & 0.00 & 2.89 & 3.57 \\
\hline Quadrula quadrula & 0.00 & 0.00 & 5.98 & 75.00 & 2.61 & 33.33 & 2.35 & 29.76 \\
\hline Obovaria reflexa & 1.63 & 25.00 & 4.89 & 41.67 & 1.65 & 18.75 & 2.11 & 23.81 \\
\hline Amblema plicata plicata & 2.45 & 37.50 & 3.26 & 41.67 & 1.51 & 20.83 & 2.03 & 28.57 \\
\hline Fusconaia ebena & 1.90 & 20.83 & 3.80 & 25.00 & 1.10 & 14.58 & 1.72 & 17.86 \\
\hline Ligumia recta & 1.09 & 16.67 & 0.00 & 0.00 & 2.48 & 29.17 & 1.72 & 21.43 \\
\hline Ellipsaria lineolata & 0.27 & 4.17 & 2.72 & 33.33 & 1.38 & 16.67 & 1.25 & 15.48 \\
\hline Lampsilis cardium & 1.36 & 20.83 & 0.00 & 0.00 & 0.83 & 12.50 & 0.86 & 13.10 \\
\hline Megalonaias nervosa & 1.63 & 20.83 & 0.00 & 0.00 & 0.55 & 8.33 & 0.78 & 10.71 \\
\hline Fusconaia subrotunda & 0.82 & 8.33 & 0.00 & 0.00 & 0.28 & 4.17 & 0.39 & 4.76 \\
\hline Obovaria subrotunda & 0.82 & 12.50 & 0.00 & 0.00 & 0.00 & 0.00 & 0.23 & 3.57 \\
\hline Leptodea fragilis & 0.00 & 0.00 & 0.00 & 0.00 & 0.28 & 4.17 & 0.16 & 2.38 \\
\hline Pleurobema coccineum & 0.00 & 0.00 & 0.00 & 0.00 & 0.14 & 2.08 & 0.08 & 1.19 \\
\hline Lampsilis siliquoidea & 0.00 & 0.00 & 0.00 & 0.00 & 0.14 & 2.08 & 0.08 & 1.19 \\
\hline Lasmigonia costata & 0.27 & 4.17 & 0.00 & 0.00 & 0.00 & 0.00 & 0.08 & 1.19 \\
\hline Plethobasus cyphyus & 0.00 & 0.00 & 0.00 & 0.00 & 0.14 & 2.08 & 0.08 & 1.19 \\
\hline Total individuals & \multicolumn{2}{|c|}{368} & \multicolumn{2}{|c|}{184} & \multicolumn{2}{|c|}{727} & \multicolumn{2}{|c|}{1279} \\
\hline Total species & \multicolumn{2}{|c|}{17} & \multicolumn{2}{|c|}{11} & \multicolumn{2}{|c|}{19} & \multicolumn{2}{|c|}{22} \\
\hline Total samples & \multicolumn{2}{|c|}{24} & \multicolumn{2}{|c|}{12} & \multicolumn{2}{|c|}{48} & \multicolumn{2}{|c|}{84} \\
\hline
\end{tabular}




\section{Appendix A Freshwater Mussels Collected from Upper Ohio River Using Quantitative Methods}




\begin{tabular}{|c|c|c|c|c|c|}
\hline \multicolumn{6}{|c|}{$\begin{array}{l}\text { Table A1 } \\
\text { Percent Species Abundance of Native Mussels Collected at } \\
\text { Ohio River Mile 284, September } 1998\end{array}$} \\
\hline \multirow[b]{2}{*}{ Species } & \multicolumn{4}{|c|}{ Subsite Number } & \multirow[b]{2}{*}{ Total } \\
\hline & 1 & 2 & 3 & 4 & \\
\hline E. crassidens & 0.00 & 0.00 & 25.00 & 48.15 & 31.03 \\
\hline Q. p. pustulosa & 0.00 & 0.00 & 10.00 & 22.22 & 13.79 \\
\hline O. reflexa & 41.67 & 0.00 & 15.00 & 7.41 & 6.90 \\
\hline E. lineolata & 8.33 & 20.00 & 10.00 & 3.70 & 6.90 \\
\hline A. ligamentina & 0.00 & 0.00 & 10.00 & 7.41 & 6.90 \\
\hline T. truncata & 8.33 & 0.00 & 5.00 & 0.00 & 6.90 \\
\hline Q. metanevra & 0.00 & 0.00 & 0.00 & 3.70 & 10.34 \\
\hline A. p. plicata & 16.67 & 0.00 & 5.00 & 0.00 & 0.00 \\
\hline$P$. alatus & 8.33 & 20.00 & 0.00 & 0.00 & 3.45 \\
\hline L. recta & 0.00 & 20.00 & 10.00 & 0.00 & 0.00 \\
\hline T. donaciformis & 16.67 & 20.00 & 0.00 & 0.00 & 0.00 \\
\hline L. fragilis & 0.00 & 0.00 & 5.00 & 3.70 & 0.00 \\
\hline F. ebena & 0.00 & 0.00 & 0.00 & 0.00 & 6.90 \\
\hline L. cardium & 0.00 & 20.00 & 0.00 & 0.00 & 3.45 \\
\hline L. complanata & 0.00 & 0.00 & 5.00 & 0.00 & 0.00 \\
\hline Q. quadrula & 0.00 & 0.00 & 0.00 & 0.00 & 3.45 \\
\hline P. cordatum & 0.00 & 0.00 & 0.00 & 3.70 & 0.00 \\
\hline Total individuals & 12 & 5 & 20 & 27 & 29 \\
\hline Total species & 6 & 5 & 10 & 8 & 11 \\
\hline$\%$ Individuals < $30 \mathrm{~mm}$ & 41.66 & 20 & 25 & 7.41 & 10.71 \\
\hline$\%$ Species < $30 \mathrm{~mm}$ & 50 & 20 & 50 & 25 & 27.27 \\
\hline Menhinick's index & 1.73 & 2.24 & 2.23 & 1.59 & 2.04 \\
\hline Species diversity $H^{\prime}$ & 1.58 & 1.61 & 2.15 & 1.56 & 2.14 \\
\hline Evenness & 1.16 & 0.00 & 1.34 & 0.72 & 0.95 \\
\hline
\end{tabular}




\begin{tabular}{|c|c|c|c|c|c|}
\hline \multicolumn{6}{|c|}{$\begin{array}{l}\text { Table A2 } \\
\text { Percent Species Occurrence of Native Mussels Collected at } \\
\text { Ohio River Mile 284, September } 1998\end{array}$} \\
\hline \multirow[b]{2}{*}{ Species } & \multicolumn{4}{|c|}{ Subsite Number } & \multirow[b]{2}{*}{ Total } \\
\hline & 1 & 2 & 3 & 4 & \\
\hline E. crassidens & 0.00 & 0.00 & 40.00 & 90.00 & 70.00 \\
\hline O. reflexa & 50.00 & 0.00 & 30.00 & 10.00 & 20.00 \\
\hline Q.p.pustulosa & 0.00 & 0.00 & 20.00 & 40.00 & 30.00 \\
\hline E. lineolata & 10.00 & 10.00 & 20.00 & 10.00 & 20.00 \\
\hline A. ligamentina & 0.00 & 0.00 & 20.00 & 10.00 & 10.00 \\
\hline Q. metanevra & 0.00 & 0.00 & 0.00 & 10.00 & 30.00 \\
\hline T. truncata & 10.00 & 0.00 & 10.00 & 0.00 & 20.00 \\
\hline T. donaciformis & 20.00 & 10.00 & 0.00 & 0.00 & 0.00 \\
\hline$P$. alatus & 10.00 & 10.00 & 0.00 & 0.00 & 10.00 \\
\hline L. recta & 0.00 & 10.00 & 20.00 & 0.00 & 0.00 \\
\hline L. fragilis & 0.00 & 0.00 & 10.00 & 10.00 & 0.00 \\
\hline L. cardium & 0.00 & 10.00 & 0.00 & 0.00 & 10.00 \\
\hline A. p. plicata & 10.00 & 0.00 & 10.00 & 0.00 & 0.00 \\
\hline F. ebena & 0.00 & 0.00 & 0.00 & 0.00 & 20.00 \\
\hline Q. quadrula & 0.00 & 0.00 & 0.00 & 0.00 & 10.00 \\
\hline P. cordatum & 0.00 & 0.00 & 0.00 & 10.00 & 0.00 \\
\hline L. complanata & 0.00 & 0.00 & 10.00 & 0.00 & 0.00 \\
\hline Total samples & 10 & 10 & 10 & 10 & 10 \\
\hline
\end{tabular}




\begin{tabular}{|c|c|c|c|c|c|}
\hline \multicolumn{6}{|c|}{$\begin{array}{l}\text { Table A3 } \\
\text { Percent Species Abundance of Native Mussels Collected at } \\
\text { Ohio River Mile 287, September } 1998\end{array}$} \\
\hline \multirow[b]{2}{*}{ Species } & \multicolumn{4}{|c|}{ Subsite Number } & \multirow[b]{2}{*}{ Total } \\
\hline & 1 & 2 & 3 & 4 & \\
\hline Q.p.pustulosa & 33.33 & 35.29 & 30.00 & 52.94 & 38.10 \\
\hline O. reflexa & 22.22 & 29.41 & 30.00 & 17.65 & 25.40 \\
\hline E. crassidens & 0.00 & 17.65 & 5.00 & 11.76 & 9.52 \\
\hline A. p. plicata & 22.22 & 0.00 & 5.00 & 5.88 & 6.35 \\
\hline E. lineolata & 0.00 & 17.65 & 0.00 & 0.00 & 4.76 \\
\hline M. nervosa & 0.00 & 0.00 & 5.00 & 5.88 & 3.17 \\
\hline P. cordatum & 11.11 & 0.00 & 5.00 & 0.00 & 3.17 \\
\hline L. recta & 11.11 & 0.00 & 0.00 & 5.88 & 3.17 \\
\hline L. fragilis & 0.00 & 0.00 & 5.00 & 0.00 & 1.59 \\
\hline$P$. alatus & 0.00 & 0.00 & 5.00 & 0.00 & 1.59 \\
\hline Q. quadrula & 0.00 & 0.00 & 5.00 & 0.00 & 1.59 \\
\hline L. teres & 0.00 & 0.00 & 5.00 & 0.00 & 1.59 \\
\hline Total individuals & 9 & 17 & 20 & 17 & 63 \\
\hline Total species & 5 & 4 & 10 & 6 & 12 \\
\hline$\%$ Individuals $<30 \mathrm{~mm}$ & 33.30 & 47.06 & 40.00 & 41.17 & 41.27 \\
\hline$\%$ Species < $30 \mathrm{~mm}$ & 60.00 & 75.00 & 50.00 & 50.00 & 50.00 \\
\hline Menhinick's index & 1.67 & 0.97 & 2.23 & 1.45 & 1.51 \\
\hline Species diversity $H$ & 1.52 & 1.34 & 1.92 & 1.39 & 1.85 \\
\hline Evenness & 1.73 & 1.20 & 0.92 & 0.79 & 0.67 \\
\hline
\end{tabular}




\begin{tabular}{|c|c|c|c|c|c|}
\hline \multicolumn{6}{|c|}{$\begin{array}{l}\text { Table A4 } \\
\text { Percent Species Abundance of Native Mussels Collected at } \\
\text { Ohio River Mile 287, September } 1998\end{array}$} \\
\hline \multirow[b]{2}{*}{ Species } & \multicolumn{4}{|c|}{ "Subsite Number } & \multirow[b]{2}{*}{ Total } \\
\hline & 1 & 2 & 3 & 4 & \\
\hline Q.p.pustulosa & 30.00 & 440.00 & 50.00 & 70.00 & 38.00 \\
\hline O. reflexa & 20.00 & 40.00 & 50.00 & 30.00 & 28.00 \\
\hline E. crassidens & 0.00 & 30.00 & 10.00 & 20.00 & 12.00 \\
\hline A. p. plicata & 20.00 & 0.00 & 10.00 & 10.00 & 8.00 \\
\hline E. lineolata & 0.00 & 30.00 & 0.00 & 0.00 & 6.00 \\
\hline M. nervosa & 0.00 & 0.00 & 10.00 & 10.00 & 4.00 \\
\hline P. cordatum & 10.00 & 0.00 & 10.00 & 0.00 & 4.00 \\
\hline L. recta & 10.00 & 0.00 & 0.00 & 10.00 & 4.00 \\
\hline L. fragilis & 0.00 & 0.00 & 10.00 & 0.00 & 2.00 \\
\hline P. alatus & 0.00 & 0.00 & 10.00 & 0.00 & 2.00 \\
\hline Q. quadrula & 0.00 & 0.00 & 10.00 & 0.00 & 2.00 \\
\hline L. teres & 0.00 & 0.00 & 10.00 & 0.00 & 2.00 \\
\hline Total quadrats & 10 & 10 & 10 & 10 & 40 \\
\hline
\end{tabular}

\begin{tabular}{|c|c|c|}
\hline \multicolumn{3}{|c|}{$\begin{array}{l}\text { Table A5 } \\
\text { Percent Species Abundance of Native Mussels Collected at } \\
\text { Ohio River Mile 290, September } 1998\end{array}$} \\
\hline Species & Percent Abundance & Percent Occurrence \\
\hline Q.p.pustulosa & 50.00 & 70.00 \\
\hline A. p. plicata & 10.71 & 20.00 \\
\hline A. ligamentina & 7.14 & 20.00 \\
\hline Q. metanevra & 7.14 & 20.00 \\
\hline E. lineolata & 7.14 & 20.00 \\
\hline$P$. alatus & 7.14 & 20.00 \\
\hline P. cordatum & 3.57 & 10.00 \\
\hline E. crassidens & 3.57 & 10.00 \\
\hline Q. quadrula & 3.57 & 10.00 \\
\hline Total individuals & 28 & \\
\hline Total species & 9 & \\
\hline Total quadrats & 10 & \\
\hline Individuals $<30 \mathrm{~mm}$ & 14.28 & \\
\hline Species $<30 \mathrm{~mm}$ & 22.22 & \\
\hline Menhinick's index & 1.51 & \\
\hline Species diversity $H$ & 1.85 & \\
\hline Evenness & 0.67 & \\
\hline
\end{tabular}




\begin{tabular}{|c|c|c|c|c|c|}
\hline \multicolumn{6}{|c|}{$\begin{array}{l}\text { Table A6 } \\
\text { Percent Species Abundance of Native Mussels Collected at } \\
\text { Ohio River Mile 292, September } 1998\end{array}$} \\
\hline \multirow[b]{2}{*}{ Species } & \multicolumn{2}{|c|}{ Subsite 1} & \multicolumn{2}{|c|}{ Subsite 2} & \multirow[b]{2}{*}{ Total } \\
\hline & Abundance & Frequency & Abundance & Frequency & \\
\hline$\overline{\overline{\text { A.p.p.plicata }}}$ & 0.00 & 0.00 & 100.00 & 30.00 & $\overline{\overline{75.00}}$ \\
\hline O. reflexa & 100.00 & 10.00 & 0.00 & 0.00 & 25.00 \\
\hline Total individuals & 1 & & 3 & & 4 \\
\hline Total species & 1 & & 1 & & 2 \\
\hline Total samples & & 10 & & 10 & 20 \\
\hline$\%$ Individuals $<30 \mathrm{~mm}$ & 0.00 & & 66.67 & & 50.00 \\
\hline$\%$ Species $<30 \mathrm{~mm}$ & 0.00 & & 100.00 & & 50.00 \\
\hline
\end{tabular}




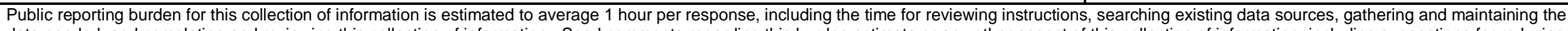

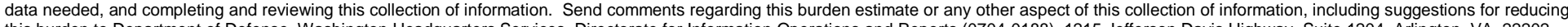

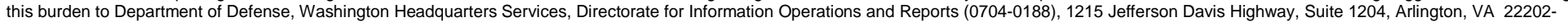

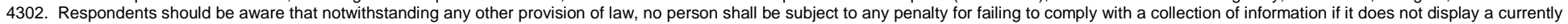
valid OMB control number. PLEASE DO NOT RETURN YOUR FORM TO THE ABOVE ADDRESS.

\begin{tabular}{l|l|l} 
1. REPORT DATE (DD-MM- $Y Y Y Y)$ & 2. REPORT TYPE & 3ATES COVERED (FrOm - To)
\end{tabular}

October 2000

\section{TITLE AND SUBTITLE}

Final Report

An Analysis of Freshwater Mussels (Unionidae) in the Upper Ohio River near Huntington, West Virginia, 1998 Studies

5a. CONTRACT NUMBER

5b. GRANT NUMBER

5c. PROGRAM ELEMENT NUMBER

6. AUTHOR(S)

Andrew C. Miller, Barry S. Payne

5d. PROJECT NUMBER

5e. TASK NUMBER

5f. WORK UNIT NUMBER

\section{PERFORMING ORGANIZATION NAME(S) AND ADDRESS(ES)}

8. PERFORMING ORGANIZATION REPORT NUMBER

U.S. Army Engineer Research and Development Center

Environmental Laboratory

ERDC/EL TR-00-15

3909 Halls Ferry Road

Vicksburg, MS 39180-6199

9. SPONSORING / MONITORING AGENCY NAME(S) AND ADDRESS(ES)

10. SPONSOR/MONITOR'S ACRONYM(S)

U.S. Army Engineer District, Huntington

502 Eighth Street

Huntington, WV 25701-2070

11. SPONSOR/MONITOR'S REPORT NUMBER(S)

\section{DISTRIBUTION / AVAILABILITY STATEMENT}

Approved for public release; distribution is unlimited.

\section{SUPPLEMENTARY NOTES}

\section{ABSTRACT}

A survey to assess community characteristics, density, population demography of dominant species, and the likelihood of finding endangered species of freshwater mussels (Unionidae), was conducted in the upper Ohio River (approximate River Miles (RM) 292-284) near Huntington, WV, in September 1998. This was the third study year to assess impacts of commercial navigation traffic in the Ohio River. Similar studies were conducted in 1992 and 1993.

In 1998 over 1,200 freshwater mussels representing 22 species were collected using qualitative methods. Mean densities of native unionids were low in 1998; maximum density was less than 8 individuals/sq $\mathrm{m}$ at RM 284 and 287. Although densities have been low and variable among years and sites, there are no specific temporal or spatial trends at this location. In 1998 the percentage of individuals less than $30 \mathrm{~mm}$ total shell length ranged from 14 to 41 percent, a substantial increase over the earlier two study years. The number of species identified in this reach of the Ohio River (qualitative and quantitative samples combined) has gradually increased during the study period. In 1992, 21 species were collected; in 1993, 25 species were found; and in 1998, a total of 26 species were collected. A total of 30 species have been found in this river reach during the three study years.

(Continued)

\section{SUBJECT TERMS}

Freshwater mussels

Navigation traffic impacts

\begin{tabular}{|c|c|c|c|c|c|}
\hline \multicolumn{3}{|c|}{ 16. SECURITY CLASSIFICATION OF: } & \multirow{2}{*}{$\begin{array}{l}\text { 17. LIMITATION } \\
\text { OF ABSTRACT }\end{array}$} & \multirow{2}{*}{$\begin{array}{l}\text { 18. NUMBER } \\
\text { OF PAGES }\end{array}$} & \multirow{2}{*}{$\begin{array}{l}\text { 19a. NAME OF RESPONSIBLE PERSON } \\
\begin{array}{l}\text { 19b. TELEPHONE NUMBER (include area } \\
\text { code) }\end{array}\end{array}$} \\
\hline $\begin{array}{l}\text { a. REPORT } \\
\text { UNCLASSIFIED }\end{array}$ & b. ABSTRACT & $\begin{array}{l}\text { c. THIS PAGE } \\
\text { UNCLASSIFIED }\end{array}$ & & & \\
\hline
\end{tabular}




\section{4. (Concluded)}

Although density of zebra mussels (Dreissena polymorpha) has increased in the study area, mean density was estimated at less than 100 individuals/sq $\mathrm{m}$. Fifteen percent of the native mussels harbored no attached zebra mussels, and 41.5 percent had from one to nine attached zebra mussels. Only 18.5 percent were heavily infested. Density of Corbicula fluminea has declined considerably. Maximum density in 1992 was over 3,000 individuals/sq m; at the same site in 1998 the density was less than 100 individuals/sq m. Based on evidence of recent recruitment and continued existence of uncommon species, conditions at this bed have improved since the early 1990s. 